\title{
Why do Foreign Investors Demand Comparability? Evidence from Unsponsored ADRs
}

\author{
Alon Kalay \\ Michigan State University - Broad College of Business \\ Rodrigo Verdi \\ Massachusetts Institute of Technology (MIT) - Sloan School of Management \\ Forester Wong \\ University of Southern California - Leventhal School of Accounting
}

July 2020

\begin{abstract}
We study the sources of demand for accounting comparability. We hypothesize that U.S. investors interested in investing in a foreign firm potentially have two different types of demands for comparability: (i) comparability to U.S. firms which report under U.S. GAAP (which we label as U.S. comparability) and (ii) comparability to other foreign firms which the investor is interested in investing in (which we label as regional comparability). The findings in prior literature examining U.S. institutional investors are consistent with channel (i). We explore unsponsored ADRs as a setting where we expect channel (ii) to be particularly important. We find that regional (but not U.S.) comparability increases the ex-ante likelihood that a depository bank selects a foreign firm for the creation of unsponsored ADRs, and the ex-post trading in the unsponsored ADR by U.S. investors. Our results imply an implicit tradeoff in the costs and benefits of increased comparability to a specific set of firms and suggests that future research could consider not only if comparability matters in a specific context, but also to whom it is aimed for.
\end{abstract}

Keywords: Accounting comparability; Unsponsored cross listing; Institutional investors; Information processing costs.

We appreciate comments received from Matthias Breuer, Mark DeFond, Nemit Shroff, and participants at the Columbia University brownbag presentation. 


\section{Introduction}

In this paper, we study the sources of demand for comparability to highlight that the demand for comparability is context specific and, as such, that "optimal" comparability is unlikely to be a one size fits all construct. Accounting comparability (hereafter comparability) has received considerable attention among academics and regulators in the recent decade with ample evidence on the consequences of comparability. ${ }^{1}$ Underlying prior findings is the belief that investors demand comparability because it reduces information processing costs (e.g., Bradshaw et al., 2004; Covrig et al., 2007; De Franco et al., 2011). More recent studies focus on providing direct evidence of investors' demand for comparability. Specifically, Fang et al. (2015) show that an increase in U.S. institutional ownership in foreign firms is associated with an increase in comparability between these foreign firms and their U.S. peers. Their results suggest that U.S. investors demand foreign firms to be comparable to U.S. peers because it facilitates monitoring.

We propose an alternative, but not mutually exclusive, view. We hypothesize that the demand for comparability varies for different users and, as a result, investors' demand for comparability is context specific. Specifically, we argue that U.S. investors interested in investing in a foreign firm potentially demand two types of comparability: (i) comparability to U.S. firms which report under U.S. GAAP (which we label as U.S. comparability) which lowers information acquisition costs and facilitates monitoring; and (ii) comparability to other foreign firms, which helps investors learn about related foreign investment opportunities (which we label as regional

\footnotetext{
${ }^{1}$ For example, prior research finds earnings comparability is associated with increased foreign ownership, analyst following, forecast accuracy, and lower forecast dispersion and crash risk (e.g., DeFond et al. 2011; De Franco et al., 2011; Wang, 2014; Fang et al., 2015, 2017, Kim et al., 2016).
} 
comparability). While channel (i) is consistent with the evidence in Fang et al. (2015), we study a setting in which we expect channel (ii) to be important. ${ }^{2}$

To achieve our goal, we focus on the depository bank's decision to create an unsponsored ADR program, or an unsponsored cross-listing, for a foreign firm post-2008. Prior to 2008, depository banks required the participation of an underlying foreign firm to create an ADR. Therefore, the decision to cross-list was driven by the underlying firm. Hence, any relation between the creation of an ADR and the financial reporting characteristics (such as comparability) of the underlying firm may result from the firm's desire to cross-list, and its related operating and reporting choices. In contrast, since 2008, depository banks can create an unsponsored ADR certificate (UADR) without any direct involvement, participation, or permission from the underlying foreign firm. As a result, the creation of an unsponsored cross-listing is aimed only at fulfilling the demand of U.S. investors, and became separate from the firm's desire to cross list (Iliev et al. 2014). Therefore, we utilize the UADR setting to isolate the demand for comparability and take the firm's incentive to supply information that is more/less comparable as given.

Our analysis is divided in two parts. First, we examine the ex-ante choice of the depository bank to create an UADR for a foreign firm as a proxy for the depository bank's expectation of U.S. investors' demand for the UADR. In addition, we examine trading in UADRs as an ex-post measure of U.S. investors' demand for the UADR and, as our tests attempt to isolate, their revealed preference for comparability. An additional important feature of our setting is that the UADR market helps identify U.S. investors who are interested in increasing the foreign exposure of their

\footnotetext{
${ }^{2}$ As we elaborate below, our hypothesis is not inconsistent with the findings in Fang et al. (2015). Rather, the settings in the two papers complement each other to illustrate a more holistic view of the various demands for accounting comparability.
} 
portfolio. ${ }^{3}$ Hence, it is natural to expect that these investors may demand comparability to help them evaluate foreign investment opportunities.

Consistent with prior literature, our primary goal is to examine the role of accounting comparability in lowering information processing cost and facilitating foreign investment (e.g., DeFond et al., 2011). However, in contrast to prior research that examines comparability driven by variation in accounting standards (e.g., DeFond et al., 2011; Barth et al., 2012), we focus on within standard variation in accounting comparability as opposed to variation in the degree of IFRS or U.S. GAAP adoption. Specifically, our tests controls for variation in accounting standards (one of the UADR determinants documented in Iliev et al., 2014) and exploits within-standard acrossfirm variation in comparability driven by accounting choices.

Following Fang et al. (2015), we utilize a measure of accounting comparability from De Franco, Kothari and Verdi (2011), hereafter DKV, adapted for foreign firms. Specifically, we create three distinct versions of the DKV measure. First, comparability to firms in the same region (Comp Region) where regions are defined according to the MSCI World Index. We employ the MSCI World Index definition of regions because it is a common framework utilized by investors to build a global market equity portfolio. Second, comparability to firms in the same foreign country (Comp Country). Third, comparability to firms in the U.S. (Comp U.S.). We employ two measures of foreign comparability, Comp Region and Comp Country, because the relevant opportunity set for a U.S. investor is unobservable and can pertain to a foreign country or region. Comp U.S. is our measure of U.S. comparability. The comparability measures for each firm $i$ employ the same firm-level returns and earnings $\left(R_{i}, E_{i}\right)$ but different peer firms $j$. For example, for a German firm i, Comp Region compares firm $i$ to all industry peer firms $j$ in Europe, the region

\footnotetext{
${ }^{3}$ Institutional holdings in firms cross-listed in the U.S. averaged approximately $12 \%$ of assets under management between 2009 and 2013 compared to only 6\% during 2003-2008 (see also Section 2.1).
} 
Germany is in according to the MSCI World Index. Comp Country compares firm $i$ to all industry peer firms $j$ in Germany, while Comp U.S. compares firm $i$ to all industry peer firms $j$ in the U.S.

As alternative measures of accounting comparability, we employ the comparability measures in Lang and Stice-Lawrence (2015) which are based on the textual cosine similarity of firms' annual reports. Comp US Text is the textual comparability of a firm's $10 \mathrm{~K}$ to its U.S. peers while Comp NonUS Text is the textual comparability of a foreign firm's $10 \mathrm{~K}$ to all its non-U.S. peers, which are not in the firm's home country. We view Comp NonUS Text (Comp US Text) as an alternative measure for Comp Region (Comp US). ${ }^{4}$

In addition to accounting comparability, we also examine the role of economic synchronicity in our findings to parse out the influence of economic similarity from accounting choices. U.S. investors attempting to increase their exposure in a foreign country or region likely prefer firms that have not only increased foreign accounting comparability, but also increased return synchronicity with other firms in the same region or country. Therefore, we create three economic synchronicity measures based on the correlation of firms' stock returns, Return Region, Return Country and Return US, following the same approach used to create the financial accounting-based measures.

We show that depositary banks are more likely to create UADRs for firms with higher levels of comparability relative to firms in the same region (Comp Region), and to a lesser extent to firms in the same country (Comp Country). In contrast, comparability to U.S. firms (Comp US) does not affect the decision to create a UADR. Not surprisingly, we find similar results when we

\footnotetext{
${ }^{4}$ The textual based measures can only be calculated for firms that issue annual reports in English and have a full text $10-\mathrm{K}$ available in Osiris, significantly reducing our sample size and the number of countries represented. Moreover, due to the computational complexity of the measure, we are limited to using the Comp NonUS Text measure from Lang and Stice-Lawrence (2015), which includes all non-U.S. peers outside firm (i)'s home country as opposed to non-U.S. peers only from firm i's region. For these reasons, we employ the textual measures as alternative measures. We find similar results using these alternative measures throughout our analyses
} 
employ the return-based synchronicity measures. The creation of an UADR is more likely for firms with more synchronous returns to those of other firms in the same region (Return Region) or country (Return Country), but not the U.S (Return US). More importantly, when we include the synchronicity and comparability measures in the same regression, the coefficients on Comp Region and Comp Country remain positive and significant with similar magnitudes suggesting that are incremental to economic similarity.

Our findings related to the UADR creation are robust to controlling for whether the firm reports using IFRS or U.S. GAAP, and we find similar results when we exclude all firm-years where the firm's financial statements are prepared in accordance with IFRS. Therefore, our results are not merely a manifestation of IFRS adoption as in DeFond et al. (2011). Moreover, similar to our results using Comp Region and Comp US, we find that only Comp NonUS Text is positively, and statistically significantly, related to the creation of an UADR while Comp US Text has an insignificant relation.

In sum, our results are consistent with the demand for regional, but not U.S., comparability in the UADR setting and highlight that accounting based comparability has an incremental effect on foreign investment decisions, over and above economic synchronicity.

We next proceed to examine how comparability relates to the ex-post trading volume in the UADR. If U.S. investors demand comparability, then comparability should not only relate to the ex-ante decision of the depository banks to create an UADR, but also to the trading volume by investors in the UADR (i.e., an ex-post rationale). Using this logic, we again find evidence supporting the demand for regional, but not U.S, comparability in our setting.

We show that comparability relative to firms in the same region (Comp Region) and country (Comp Country) predicts future trading volume, whereas comparability to firms in the 
U.S. (Comp U.S.) does not. The inclusion of the economic synchronicity measures does not significantly change the coefficients for Comp Region and Comp Country. Interestingly, Return Region is positively related to future trading volume while Return US is negatively related, consistent with the idea that investors in UADR are interested in increasing their exposure to foreign markets. Using our alternative textual measures, we find that Comp NonUS Text predicts future UADR trading volume while Comp US Text is unrelated to UADR trading volume. Taken together, our findings with respect to the ex-ante selection of the firm and the ex-post trading volume in the UADR are consistent with U.S. investors' demand for regional comparability in the unsponsored cross-listing setting.

Having established our main results related to the sources of comparability influencing the decision of the depository bank to issue an UADR, and the trading activities of U.S. investors, in the second part of our analysis we exploit two contrasting settings to shed light on the forces underlying our results. First, we contrast unsponsored ADRs with sponsored cross-listings. Prior research suggests that firms choose to cross-list on U.S. exchanges in order to bond with the U.S. regulatory regime as a way to increase transparency and lower agency costs (Coffee, 2002; Doidge, 2004; Doidge et al., 2004), thus lowering their cost of capital (Hail and Leuz, 2009). As part of these efforts, firms that cross-list on U.S. exchanges using level 2 or 3 ADRs (ADR hereafter) exhibit higher levels of financial reporting quality prior to cross-listing, and experience increases in financial reporting quality after they cross-list (Lang et al., 2003). If comparability to U.S. GAAP is associated with higher financial reporting quality and facilitates the monitoring of foreign firm by U.S. regulators (e.g., Fang et al. 2015), then ADRs are predicted to have financial reports that are more comparable to those of their U.S. peers, in contrast to the findings for UADRs. 
Consistent with these predictions, we find that cross-listing firms with ADRs are more comparable to their U.S. peers, relative to other foreign firms. Moreover, the comparability of these firms with their U.S. peers increases following the cross-listing. In addition, we find no association between the decision to cross-list and regional- or country-level comparability. These results suggest firms choose to cross-list to differentiate themselves from their local peers and commit to a stronger regulatory regime. In contrast, in the case of UADRs, the listing decision of the depository banks and the trading activity of U.S. investors reflects a preference for comparability with foreign peers, presumably to better evaluate foreign investment opportunities.

Second, to illustrate the potential trade-off firms face with respect to accounting comparability, we contrast the relation between comparability and the trading activity of local investors with those of US investors in the UADR market. We show that in our full sample of foreign firms there is a positive association between our regional measures (Comp Region and Comp Country) and trading in the firm's local market, indicating a benefit of comparability to local investors. However, among all cross listed firms (both sponsored and unsponsored), higher levels of comparability to U.S. peers is negatively related to local trading volume. Therefore, firms with ADRS that increase their U.S. comparability sacrifice some local trading volume in order to facilitate raising foreign capital.

Taken together, our results with respect to sponsored cross-listing help demonstrate that comparability is unlikely to be a one size fits all construct. Instead, it is better thought of as a setting-specific construct, an insight highlighted by Dechow et al. (2010) in the context of earnings quality that has been somewhat absent in the comparability literature.

Our analyses thus far suggest that U.S. investors value local/regional comparability in UADRs because it helps them evaluate investment opportunities. To shed light on this channel, 
we examine the holdings of U.S. institutional investors in the ADR market before the change in regulation regarding the creation of UADRs. If investors' opportunity sets consist mainly of firms in one particular region, then investors who have pre-existing ADR holdings in a region are more likely to acquire UADR from the same region, following the change in regulation. Consistent with this conjecture, we find that an investor's total pre-existing holdings in a region strongly relate to her future UADR investments following the regulation change, in the same region.

Moreover, if investors demand comparability because it helps them evaluate potential investment opportunities, then comparability is more beneficial when a larger proportion of firms within an opportunity set are comparable. In other words, if investors' opportunity sets are defined by region, it will be easier for them to utilize UADRs when there are a larger number of comparable firms within a region. Consistent with this conjecture, we find a positive relation between the mutual fund holdings in an UADR, and the average comparability of the region the underlying firm is in, after controlling for firm-level comparability. These findings suggest that regional comparability facilitates the expansion of U.S. investors' foreign portfolios.

One advantage of our UADR setting is that firms do not choose to create an UADR, thus alleviating concerns related to reverse causality and self-selection which are often present when examining the link between earnings characteristics and market outcomes (especially in a crosslisting setting). Nonetheless, a remaining concern is that our results are driven by an unobservable characteristic which is correlated with accounting comparability. We take several steps to address this concern. First, in our main analyses we include a set of likely control variables as well as country, industry, and year fixed-effects to remove time-invariant heterogeneity in these characteristics. Second, we control for and analyze the role of the underlying firm's return synchronicity with other firms in the same country or region. Third, as additional analyses, we 
show that comparability to the region and country matter more when the firm has higher accounting quality. However, the relation between return synchronicity and the decision to create an UADR does not vary with financial reporting quality. These additional analyses support our underlying assumption that the comparability measures capture a characteristic of the accounting system.

Overall, our findings complement the evidence in Fang et al. (2015) which shows that U.S. institutional investors prefer comparability to U.S. GAAP reporting, due to the role of comparability in the monitoring of foreign firms. In combination with their paper, our results demonstrate that the demand for comparability is context specific and can vary for different users, highlighting the importance of relevant peer group when measuring comparability.

While our setting attempts to isolate the demand channel as in Fang et al. (2015), the setting we employ is substantially different because U.S. investors in UADRs are passive investors with little (if any) influence on the underlying foreign firms. ${ }^{5}$ As such, we do not expect these investors to be able to affect foreign firms' comparability, which is the central result in Fang et al. (2015). Consistent with this argument, we fail to find subsequent increases in U.S. or regional comparability following the creation of an UADR. Therefore, our results should not be interpreted as a competing demand channel relative to the channel proposed in Fang et al. (2015). Rather, our contribution is to illustrate that alternative demand channels for comparability exist and are even likely to co-exist with varying degrees over time, based on differences in the investor base and their respective objectives.

Our results also imply an implicit tradeoff in the costs and benefits of increased comparability to a specific set of firms. For example, a German firm interested in attracting U.S.

\footnotetext{
${ }^{5}$ DeFond et al. (2011) do not attempt to isolate the demand channel as is it not the focus of their research question. We discuss further differences between our setting and theirs in Section 2.2.
} 
investors may face a trade-off between being more comparable to their regional peers versus being comparable to peer U.S. firms. Understating the underlying demand for comparability illustrates the multi-dimensional aspect of comparability. Further, it suggests that future research could examine not only if comparability matters in a specific context but also to whom it is aimed for.

Our paper proceeds as follows. Section 2 describes the institutional background of unsponsored ADRs and develops our hypotheses. Section 3 presents the sample selection and main variables of interest. Section 4 presents our research design and empirical results. Section 5 concludes.

\section{Institutional Background and Hypothesis Development}

\subsection{The Market for Unsponsored ADRs}

An unsponsored ADR (UADR) is a security created by U.S. financial institutions to facilitate trading in foreign firms by U.S. investors. UADRs are issued by U.S. depository banks and represent holdings in the underlying ordinary shares of a foreign firm, which are held in custody by the depositary bank in the issuer's home market. The depositary bank and the issuer do not enter into a deposit agreement because there is no legal relationship between the parties, unlike sponsored cross-listed firms.

The UADRs trade in the United States on the over-the-counter (OTC) markets. The establishment of a UADR is initiated by the depositary bank, mainly in response to investor demand and requires no action on the company's part in the form of legal documentation or otherwise. There are no direct costs involved to the issuer, and no incremental reporting obligations on the part of the issuer (e.g., no requirements to comply with Sarbanes- Oxley and no U.S. GAAP reconciliation). To establish a UADR, a depositary bank can independently determine that a foreign issuer meets the exemption. The depositary bank must represent that it has a "reasonable, 
good faith belief after exercising reasonable diligence" that the issuer electronically publishes the information required by Rule 12g3-2(b) including regular financial statements, annual reports and press releases in English, for example. The U.S. SEC rule change related to the exemption required by Rule 12g3-2(b) was designed to encourage the establishment of ADR facilities for more foreign issuers. Prior to October $10^{\text {th }}, 2008$, the underlying issuers (firms) had to apply for the exemption under Rule 12g3-2(b), while now the exemption is granted solely based on the depositary bank's due diligence.

From an investor perspective - UADRs provides an opportunity to access foreign securities that were previously unavailable through sponsored cross-listings within the framework of the U.S. securities infrastructure (Iliev et al., 2014). Consistently, UADRs have become a primary investment tool with which U.S. institutional investors invest in foreign firms. Institutional holdings in firms cross-listed in the U.S. averaged approximately $12 \%$ of assets under management between 2009 and 2013 compared to only 6\% during 2003-2008. This growth is driven by increases in UADR holdings (See Appendix B). Deutsch Bank (2018) further predicts that U.S. investment in foreign equities via UADRs will remain popular due to factors such as capital growth in pension funds. In total, the amounts invested in UADRs has grown by $329 \%$ over the past decade, now totaling $\$ 15.4$ billion. This growth represents a $211 \%$ increase in the number of institutional investors purchasing UADRs (Deutsche Bank, 2018). ${ }^{6}$

Iliev et al. (2014) show that depositary banks select firms for which to create UADRs based on characteristics that explain U.S. investor holdings of non- U.S. firms, such as: size, profitability,

\footnotetext{
${ }^{6}$ As of September 2018, there were more than 500 unique institutional investors investing in UADRs.
} 
and reporting under IFRS or U.S. GAAP. We utilize this setting to examine how financial statement comparability affects the bank's decision to create an UADR for a foreign firm.

\subsection{Hypothesis Development and Related Literature}

Prior literature highlights that comparability is related to various capital market outcomes. However, there is limited work aimed at understating the different types of comparability that an investor may demand. Prior literature establishes U.S. investors' desire to compare the information provided by the foreign firm to U.S GAAP (e.g., Bradshaw et al., 2004; Bae et al., 2008; Fang et al. 2015). U.S. investors may demand comparability to U.S. GAAP because they view it as a superior standard which they are also more familiar with. We label this demand for comparability as U.S. comparability. Fang et al. (2015) show that an increase in U.S. institutional ownership is associated with an increase in comparability between foreign firms and their U.S. peers, or U.S. GAAP, achieved via the use of Big4 auditors. The demand for U.S. comparability is also consistent with the home bias literature, which shows that investors perceive investments that are 'geographically closer' as superior (e.g., French and Poterba, 1991; Huberman 2001; Pool et al., 2012).

In the context of IFRS adoption, DeFond et al. (2011) find that increased uniformity across firms in the E.U. achieved via IFRS adoption increases foreign ownership by global and country specific mutual funds in firms that belong to E.U. countries with strong pre-existing credibility, and industries (within a country) that experience larger increases in uniformity. Their measure of uniformity identifies groups of firms whose accounting becomes closer to international standards (firms in industries with relatively more IFRS adoption). Therfore, the results in DeFond et al. (2011) may also be interpreted as evidence that foreign global funds view IFRS as a superior standard which they are also more familiar with. 
We hypothesize that investors may demand an additional form of comparability. Specifically, comparability across the set of firms they are evaluating. Similarity across the different firms being analyzed makes it easier for investors to process the related information. In the case of U.S. investors, lower processing costs may be driven by the comparability of firms across a specific region or market investors are evaluating. We label this portfolio driven demand for comparability as regional comparability. We note that regional comparability can exist independent of IFRS adoption and vary within counties that adopt IFRS. Distinguishing between these alternatives is important because in an international setting variation in the underlying demand for comparability may result in different policy implications and preferences for comparability to different sets of firms.

We examine the underlying demand for comparability by examining U.S. investors who invest in foreign firms using UADR. If comparability is associated with the depository bank's decision to create an UADR we assume that it is because the bank believes it will help create investor demand for the security (an assumption that we test in Hypothesis 2). We utilize this setting to examine the demand for different types of comparability by U.S. investor based on the relation between the comparability of the underlying firm's financial statements and the bank's decision to create an UADR for the foreign firm.

If the underlying demand for comparability is driven by an investor's desire to invest in U.S. GAAP like firms, then we expect the ex-ante creation of an UADR to be driven by the comparability to U.S. peers, or by U.S. comparability. Alternatively, if the underlying demand for comparability is driven by U.S. investors' desire to better evaluate alternative foreign investments opportunities, then U.S. investors would demand comparability to the peer firms being evaluated overseas, or by regional comparability. 
It is important to note that the arguments related to the demand for U.S. and regional comparability are not mutually exclusive, and it is possible that U.S. investors demand comparability to both U.S. firms and local foreign firms. Therefore, it is possible that: i) comparability is irrelevant and unrelated to the decision to create an UADR; ii) both U.S. and regional comparability relate to the creation of UADRs; iii) Only one form of comparability drives the demand for UADRs. The relation is ultimately an empirical question. Hence, we state our first hypothesis as follows:

H1a: There is a positive relation between the ex-ante creation of an UADR and the comparability of the underlying firm's financial statements to those of its U.S. peers (U.S. comparability).

H1b: There is a positive relation between the ex-ante creation of an UADR and the comparability of the underlying firm's financial statements to those of its local and regional peers (regional comparability).

In addition to the ex-ante UADR selection, the unsponsored cross-listing setting also allows us to examine how comparability relates to the ex-post trading volume in the UADR, in the U.S. OTC market. We expect a consistent relation between the type of comparability that is associated with the ex-ante creation of the UADR and the ex-post trading volume in the UADR. Hence, if the U.S. investors demand U.S. (regional) comparability then U.S. (regional) comparability should drive the ex-post trading volume in the UADR in addition to the ex-ante selection of firms. Thus, our related hypotheses, stated in the null form, are as follows.

H2a: There is a positive relation between the ex-post trading volume in the UADR and the comparability of the underlying firm's financial statements to those of its U.S. peers (U.S. comparability). 
H2b: There is a positive relation between the ex-post trading volume in the UADR and the comparability of the underlying firm's financial statements to those of its local and regional peers (regional comparability).

\section{Sample Selection and Variable Measurement}

\subsection{Sample Selection}

We obtain (a) data on cross listings from the Bank of New York, J.P. Morgan, and Citigroup's websites, and CRSP; (b) accounting data from Worldscope; (c) financial data for the local (foreign) firms from Datastream; (d) financial data for the ADRs trading in the U.S. from Bloomberg and; (e) holdings data for U.S. institutional investors from Thomson Reuters.

We begin with a sample of 216,805 non-U.S. firm-years, between 2001 and 2013, from Worldscope. We impose two sample selection criteria to ensure that our sample firms are potential firms from which depository banks can create UADRs, and that our results are not influenced by the contemporaneous accounting choices of the underlying firms. First, we remove all sponsored cross listed firms and second, we remove all firm-years after the firm has an UADR created in the U.S. These criteria ensure that the financial reporting characteristics of the firm are not related to a prior cross-listing. As a result, using the benefit of hindsight, our treatment firms consistent of firm-years in which the underlying firm will become an unsponsored cross-listed firm at some point in the future. Our control firms consistent of firms that have not been, and will not be, cross listed (sponsored or unsponsored) during our sample period.

Our final sample consist of 52,052 firm-years (7,832 unique firms) with available data to compute accounting comparability, earnings quality, earnings synchronicity, return synchronicity and the control variables. ${ }^{7}$ 3,448 firm-years (899 unique firms) correspond to firms that will be

\footnotetext{
${ }^{7}$ Our calculation of the comparability and synchronicity measures requires at least 10 observations in a county-year.
} 
unsponsored cross-listed at some point between 2008 and 2013. Details related to our sample construction are reported in Table 1.

We divide our sample of firms into regions based on the definition of the MSCI World Index. The MSCI World Index first divides countries into two markets: (1) developed markets and (2) emerging markets. Within each market, countries are grouped into regions based on their geographic locations. The developed market includes two regions (1) Europe \& The Middle East and (2) the Pacific. The emerging markets includes three regions (1) America, (2) Asia and (3) Europe \& Middle East \& Africa. The distribution of our sample across these regions is presented in Table 2.

\subsection{Variable Measurement}

In this section, we discuss the comparability measures used in our study. Detailed variable definitions of all the variables employed in our analysis are reported in Appendix A.

\subsubsection{Financial Reporting Comparability}

We follow the approach of DKV to construct our primary empirical measures of financial reporting comparability. DKV develop an empirical measure of comparability based on the closeness with which two firms' accounting functions map economic events (as reflected by stock returns) into the financial statements (as reflected by earnings). If firms have comparable accounting systems, similar economic events should result in similar earnings.

Similar to Fang, Maffett and Zhang (2015), we modify the DKV measure to capture the comparability of a non-U.S. firm's financial reporting. We measure comparability for a non-U.S. firm relative to three different sets of industry peers: (1) peers in the same geographical region (2) peers in the same country and (3) peers in the U.S. 
To estimate a non-U.S. firm's accounting comparability to peers in the same region we estimate the following rolling-window time-series regression using the past five years of data from t-4 to $\mathrm{t}$ for each non-U.S. firm $i-$ year $t$;

$$
N I_{i t}=\alpha_{i}+\beta_{i} R_{i t}+\varepsilon_{i t}
$$

where $N I_{i t}$ is the annual net income before extraordinary items in fiscal year $t$ scaled by market capitalization at the beginning of year $t$ and $R_{i t}$ is the annual stock return computed from three months after the end of fiscal year $t-1$ to three months after the end of fiscal year $t$.

We use the predicted coefficients from equation $(1), \hat{\alpha}_{i}$ and $\hat{\beta}_{i}$, as a proxy for the accounting function of firm $i$. We similarly estimate $\hat{\alpha}_{j}$ and $\hat{\beta}_{j}$, the accounting function of each firm $j$ in the same region. Based on firm i's and firm $j$ 's estimated accounting functions, we calculate $E(N I)_{i i t}$ and $E(N I)_{i j t}$, the expected earnings for firms $i$ and $j$ in year $t$ using firm $i$ 's stock return, $R_{i t}$, as follows:

$$
\begin{aligned}
& E(N I)_{i i t}=\hat{\alpha}_{i}+\hat{\beta}_{i} R_{i t}, \\
& E(N I)_{i j t}=\hat{\alpha}_{j}+\hat{\beta}_{j} R_{i t},
\end{aligned}
$$

We then define accounting comparability, $C O M P_{i j t}$, as the average absolute difference between the expected earnings for firm $i$ under firm $i$ 's and firm $j$ 's estimated accounting functions over the five-year period from $t-4$ to $t$, as follows:

$$
C O M P_{i j t}=-\frac{1}{5} \sum_{t-4}^{t}\left|E(N I)_{i i t}-E(N I)_{i j t}\right|
$$

We multiply the average difference by -1 so that larger values of $C O M P_{i j t}$ indicate greater accounting comparability. To estimate comparability to firms in the same region, Comp_Regionit, 
we measure COMPijt for each possible combination of a non-U.S. firm $i$ and firm $j$ in the same region, within the same one-digit ICB industry group during a given year $t$. Finally, we calculate our firm-year measure of comparability to other firms within the region, Comp_Region ${ }_{i t}$, as the average of the full set of COMPijt multiplied by 100 .

We follow a similar approach when estimating Comp_Countryit and Comp_USit, except that we alter the peer firms $j$ that are used to compute the measures. For Comp_Countryit firm $j$ includes all possible firms in the same country and one-digit ICB industry group as firm i. For Comp_US $S_{i t}$ firm $j$ includes all U.S. firms that are in the same one-digit ICB industry group as firm $i$.

We report descriptive statistics for the comparability measures in Table 3. As may be expected, we find that on average foreign firms are most comparable to other firms within their own country, followed by their region, and lastly relative to the U.S.

As alternative measures of accounting comparability we employ the measures used in Lang and Stice-Lawrence (2015). ${ }^{8}$ Lang and Stice-Lawrence (2015) develop textual based comparability measures that are not based on the earnings-return relationship between firms. The first measure we use is Comp_US_Text $i, t$, which measures the textual similarity of a foreign firm's $10 \mathrm{~K}$ to its U.S. peers. Similarly, the second alternative measure we employ is Comp_NonUS_Texti,t, which measures the textual similarity of a foreign firm's $10 \mathrm{~K}$ to all its non-U.S. peers which are not in the firm's home country. Comp_NonUS_Text $i_{i, t}$ (Comp_US_Text $i_{i, t}$ ) is computed as the median of each firm (i)'s $10 \mathrm{~K}$ cosine similarity with all its non-U.S. (U.S.) peers in a given year. We view Comp_NonUS_Text $t_{i, t} \quad\left(\right.$ Comp_US_Text $\left.t_{i, t}\right) \quad$ as alternative measures for Comp_Region ${ }_{i, t}$ (Comp_USi,t).

\footnotetext{
${ }^{8} \mathrm{We}$ thank the authors for providing us their data.
} 
In untabulated analysis, we find that the textual based measures are positively correlated with our primary measures, but not at very high levels, indicating they provide independent variation in comparability with which to test our hypotheses. The correlations between Comp_NonUS_Text $i_{i, t}$ (Comp_US_Text $\left.{ }_{i, t}\right)$ and Comp_Region ${ }_{i, t}\left(C_{\text {Comp_US }}, t\right)$. vary between approximately 5 and $9 \%$.

The textual based measures can only be calculated for firms that issue annual reports in English and have a full text 10-K available in Osiris. Therfore, our sample is reduced from 52,052 observations to 15,773 observations when using the alternative textual based measures. Further, the number of countries represented declines from 61 unique countries to 39. Finally, we note that our primary measure (Comp_Region $i, t)$ includes non-U.S. peers only from firm i's region while Comp_NonUS_Texti,t includes all non-U.S. peers outside firm (i)'s home country. For these reasons, we employ the textual based measures as alternative measures.

\subsubsection{Return Synchronicity}

Following DKV, to estimate a non-U.S. firm's return synchronicity (comparability) to its peers in the same region, we estimate the following rolling-window time-series regression using the past 48 months of data:

$$
\operatorname{AvgRet}_{i m}=\phi_{0 i}+\phi_{1 i} \operatorname{Ret}_{i m}+\varepsilon_{i j q}
$$

AvgRet $_{i m}$ is the average return of all other firms in the same region and industry. We define firm i's return synchronicity, Ret_Region $i t$ as the adjusted $\mathrm{R}^{2}$ from equation (9).

We follow a similar approach when estimating Ret_Countryit and Ret_US it except we alter the peer firms included when calculating $A v g \operatorname{Ret}_{i m}$. For Ret_Countryit, we include firms that are 
in the same country and industry group, while the computation of Ret_USit includes all U.S. firms that are in the same industry group.

Similar to the summary statistics pertaining to our comparability measures, Table 3 shows that firms are most synchronized with other firms in their country, followed by firms in their regions, and least synchronized with firms in the U.S. In untabulated results, we find that while the relation between the synchronicity and comparability measures is positive and significant the magnitude of the correlation is relatively small (the highest correlation observed is $2.5 \%$ ).

\section{Empirical Analysis}

\subsection{The Depository Bank's Ex-Ante Choice of Firms and Financial Statement Comparability}

To test H1a and H1b, we first test whether the initiation of an unsponsored cross listing is positively associated with financial reporting comparability. Specifically, we estimate the following firm-year level OLS regression:

$$
\begin{array}{r}
\text { Unsponsored }_{i}=\alpha+\beta_{1} \text { Comparability }_{i t}+\beta_{2} \text { Accounting_Quality }_{i t} \\
+\gamma \text { Controls }_{i t}+\varepsilon_{i t},
\end{array}
$$

Unsponsored $_{i}$ is an indicator variable equal to 1 if firm $i$ will be cross-listed at any point between 2008 and 2013. Comparability $y_{i t}$ is one of the firm-year comparability measures. Accounting_Qualityit is the principal component of three commonly used measures of accounting quality (e.g., Leuz, Nanda and Wysocki, 2003; Gopalan and Jayaraman, 2012). The first measure, EM1, captures the extent of income smoothing and equals the ratio of the standard deviation of 
operating income to the standard deviation of operating cash flow (both scaled by lagged total assets). Larger values of EM1 imply higher levels of accounting quality. The second measure, $E M 2$, is the correlation between changes in accounting accruals and changes in operating cash flows. Following Leuz, Nanda and Wysocki (2003), we interpret a more negative correlation as indication that the reported earnings are smoothed to a greater extent, and do not reflect the firm's underlying economic performance. The third measure, EM3, is the magnitude of accruals scaled by the magnitude of cash flows. Following prior literature, we interpret a greater use of accruals as increased use of discretion by managers to conceal true economic performance. We first modify EM3 such that larger values indicate higher accounting quality, and then combine EM1, EM2, and EM3 to compute Accounting_Qualityit.

Our control variables include the set of variables that Iliev et al. (2014) documents are correlated with the decision of the depositary bank to create an UADR. ${ }^{9}$ We further include country, industry, and year fixed-effects. ${ }^{10}$ Given the large number of fixed-effects employed we estimate our regression using O.L.S. instead of using Probit or Logit models.

Table 4 Panel A presents the regression results for our entire sample. The results show that unsponsored cross-listing is positively associated with comparability to the local region. In terms of economic significance, a one standard deviation increase in comparability to the local region increases the probability of being targeted by $\sim 10 \%$. We find weaker evidence that comparability to other firms in the same country is positively associated with the creation of an UADR. We find

\footnotetext{
${ }^{9}$ See Iliev et al. (2014) Table 8 column (1). We replace the variable NYSE listing eligibility with the inclusion of the firm on a worldwide major index, as defined by Worldscope, because this variable is more likely to be correlated with our comparability measures.

${ }^{10} \mathrm{We}$ find similar results when we replace the indicator variable IFRS/USGAAP with Accounting Standard fixedeffects, as defined by Worldscope.
} 
no evidence that comparability to U.S. firms increases a firm's probability of becoming an unsponsored cross-listed firm.

Consistent with U.S. investors utilizing UADRs to increase their international exposure, we find that the return synchronicity of a firm with peer firms in the same region and country is positively related to the probability of creating an UADR. More importantly, when we include the accounting-based comparability measures and the return-based synchronicity measures in the regression simultaneously (columns (5) and (6)), we continue to find positive coefficients for Comp_Region ${ }_{i t}$ and Comp_Countryit, with similar magnitudes and levels of statistical significance to those reported in columns (1) and (2). These results highlight that the role of accounting comparability in the decision to create an UADR is incremental to the role of economic similarity.

The lack of significance for the coefficient on Comp_US $i$ also alleviates concerns that our results our driven by a correlated omitted variable related to the earnings-return relation of the cross listed firms. Equations (2a) and (2b) highlight that Comp_US $i$ and Comp_Region $i t$, are computed using the same underlying earnings-returns relation for the cross-listed firms. The only difference is in the peer group. Consistently, in untabulated results we find that the Pearson (Spearman) correlation between these two measures is $0.502(0.362)$. Therefore, if the association we document was driven by the estimates from equation (2a) we would find similar results for Comp_US ${ }_{i t .}{ }^{11}$ In Appendix C, we present similar results using alternative comparability measures estimated following Barth et al. (2012).

Our primary analysis includes an indicator variable for whether the firm reports using IFRS or U.S. GAAP. Nevertheless, to further ensure that are results are not merely a manifestation of a

\footnotetext{
${ }^{11}$ We further examine the relation between our comparability measures and size to ensure that our results are not driven by a relation between size and the creation of an UADR which is not captured by our control variables. In untabulated analyses, we find that while the correlation between the comparability measures and size is positive and significant, it is small varying between $4-7 \%$.
} 
preference for firms that report using IFRS, in Panel B we re-estimate equation (4) only for the sample of firms-years where the firm does not prepare financial statements using IFRS. We continue to find a positive relation between Comp_Region ${ }_{i t}$ and the creation of an UADR, as well as between Comp_Country ${ }_{i t}$ and the creation of an UADR.

In Panel C, we employ our alternative textual based measure of comparability. We find similar results using alternative measures. The results show Comp_NonUS_Texti,t is positively related to the likelihood that a firm is selected for the creation of an UADR while the coefficient for Comp_US_Texti,t is not statistically significant.

Taken together, these results suggest that depository banks pick firms with more comparable financial statements to their regional peers, and to a lesser extent to their domestic peers, consistent with H1b. We fail to find evidence consistent with H1a. Given that depositary banks pick firms based on characteristics that stimulate investor demand, the results suggest that U.S. UADR investors prefers regional comparability and not U.S. comparability.

\subsection{Ex-Post Trading Volume in The UADR and Financial Statement Comparability}

If comparability is a characteristic that determines the ex-ante selection of a firm for the creation of an UADR, based on investor demand, then it should also relate to the ex-post trading in the UADR. Therefore, we test hypotheses $\mathrm{H} 2 \mathrm{a}$ and $\mathrm{H} 2 \mathrm{~b}$ using the ex-post trading volume of UADRs in the OTC market. Specifically, we estimate the following regression:

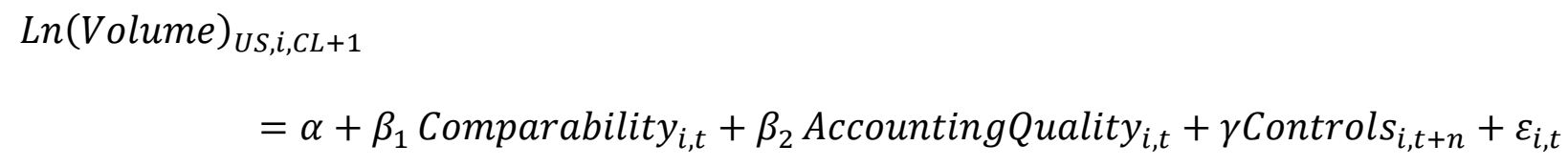


Where Ln_Volume $U S, i, C L+1$ is the sum of the daily trading volume in an unsponsored cross-listing during the year after the creation of the UADR in the U.S. market. The control variables include the variables employed in Table 4 in addition to the price of the UADR.

The results for this analysis are reported in Table 5. Consistent with $\mathrm{H} 2 \mathrm{~b}$, the results in columns (1) and (2) indicate that firms with more comparable accounting systems, relative to firms in their own region and country, experience higher trading volume levels in their UADRs. We find no relation between our U.S. based comparability measures and future trading volume in the UADR which is inconsistent with H2a. We find similar results in columns (3) and (4), when we include the return synchronicity measures in the regressions. Interestingly, trading volume is positively related to Return_Region ${ }_{i, t}$ and negatively related to Return_USA $A_{i, t}$, consistent with our conjecture that US investors utilize UADRs to increase their exposure to foreign firms.

We find similar results when we employ our textual based measures of comparability. Again, our results indicate that U.S. UADR investors appear to demand regional comparability but not U.S. comparability. ${ }^{12}$

\subsection{Sponsored Cross Listing, Local (Foreign) Trading, and Accounting Comparability}

To further support our conclusion that the demand for accounting comparability varies across users and settings, we contrast our main findings with the role of accounting comparability in sponsored cross listings. Prior research argues that firms choose to cross-list on US exchanges using level 2 or 3 ADRs (ADR hereafter) to differentiate themselves from their local peers by committing to a stronger regulatory regime, in an effort to raise foreign capital. (e.g., Coffee, 2002; Doidge, 2004; Doidge et al., 2004; Hail and Leuz, 2009). As part of this process, firms with ADRs

\footnotetext{
12 This result also confirms that the Depository Bank's decision to meet investor demand and select firms with high level of Comp Region and Comp Country is in line with the bank's incentives, because depositary banks create UADRs to generate fee income which is also achieved through trading volume.
} 
increase their financial reporting quality prior to cross-listing and experience further increases in reporting quality after they cross-list (Lang et al., 2003).

If comparability to U.S. GAAP increases financial reporting quality and facilitates the monitoring of foreign firm by U.S. regulators (e.g., Fang et al. 2015), then we predict ADRs have financial reports that are more comparable to those of their U.S. peers, in contrast to our primary findings related to UADRs. To test our prediction, we obtain a list of level 2 and level 3 ADR firms and compare them to our sample of Worldscope firms (our primary sample with the addition of the sponsored cross-listed firms) using the following model:

$$
\begin{gathered}
\text { Comparability }_{i t}=\alpha+\beta_{1} \text { ADR_Level } 23_{i}+\beta_{2} \text { ADR_Level } 23_{i} \times \text { Post }_{i t}+\beta_{3} \text { Post }_{i t} \\
+\gamma \text { Controls }_{i t}+\varepsilon_{i t},
\end{gathered}
$$

$A D R_{-}$Level $_{2} 3_{i}$ is an indicator variable which takes the value of 1 if firm $i$ will be level 2 or 3 cross-listed in the U.S. at any point between 2008 and 2013. Post $t_{i t}$ is an indicator variable which takes the value of 1 if year $\mathrm{t}$ is equal to or after firm $i$ is cross listed in the U.S.

Table 6 presents the regression results for equation 7. The coefficient for ADR_Level23i is positively related to Comp $U S_{i, t}$, indicating that firms that cross-list using ADRs have accounting information that is more comparable to that of their US peers prior to cross-listing. This result is consistent with firms taking steps to improve their financial reporting quality in anticipation of cross listing. Moreover, the coefficient for $A D R \_$Level $23_{i}{ }^{*}$ Posti,t is also positively related to Comp $U S_{i, t}$, suggesting that the level of comparability increase following the cross-listing. We find no relation between the decision to create an ADR and comparability to other peer firms in the same region or country. 
To illustrate the potential trade-off firms face with respect to accounting comparability, we examine the relation between comparability and the trading activities of local investors. Specifically, we estimate the following model:

$$
\text { ln_Volume }_{\text {Local }, t+1}=\alpha+\beta_{1} \text { ADR_Level } 23_{i}+\gamma \text { Controls }_{i t}+\varepsilon_{i t} \text {, }
$$

In_Volume Local,$t+1_{1}$ is the sum of the daily trading volume in year $\mathrm{t}+1$ in the foreign firm's local market. $^{13}$

The results are presented in Table 7. The results in column (1) show that across our full sample of foreign firms (level 2 and 3 sponsored, unsponsored and non-cross listed firms) there is a positive association between Comp Region and Comp Country, and trading volume in the firm's local market, suggesting local investors benefit from regional (local) comparability. Moreover, when we restrict our sample of firms to cross-listed firms only (unsponsored and sponsored), the results in column (2) show that higher levels of comparability to U.S. peers is negatively related to local trading volume. Overall our results suggest that ADR firms that increase U.S. comparability may sacrifice some local trading volume in order to facilitate raising foreign capital.

These results demonstrate that the demand for comparability can vary across users and is context specific. While firms with ADRs employ US comparability to facilitate monitoring and lower agency costs, at the cost of sacrificing local trading volume, depository banks create UADR to fill U.S. investor demand which is enabled by local comparability.

\subsection{UADR Investors}

\footnotetext{
${ }^{13}$ In contrast to Table 5, we use the full panel of firms because there is no obvious event time $t$.
} 
In this sub-section we explore the relation between comparability and the holdings of U.S. institutional investors, because they are the major investors in the UADR market (e.g., Deutsche Bank 2012). ${ }^{14}$ We begin by examining how an institutional investor's pre-existing holdings in a region relate to their investments in the UADR market. Next, we examine whether comparability helps institutional investors grow their international portfolio.

\subsubsection{The Role of Pre-Existing Holdings for UADR Investors}

If U.S. institutional investors focus on specific regions when investing aboard, then investors who have pre-existing ADR holdings in a particular region are more likely to acquire UADRs from the same region, following the change in regulation in 2008. Therefore, we examine whether investors who have higher levels of existing exposure to a certain region are more likely to purchase UADRs in the same region post 2008. Specifically, we estimate the following crosssectional fund-region regression:

$$
U A D R_{-} \text {Post } 08_{m, r}=\alpha+\beta_{1} \text { Region_Pre08 } 8_{m, r}+\gamma \text { Controls }_{m, p o s t}+\varepsilon_{m}
$$

In the above regression, each observation represents the average holdings that a particular fund has in a particular region. UADR_Post08 ${ }_{m, r}$ is the average additional dollar amount of investment that mutual fund $m$ invested in an UADR from region $r$ in the post SEC rule change period (2009 to 2013). Region_Pre08m,r is the average dollar amount of investment that mutual fund $m$ invested in region $r$ in the pre-SEC rule change period (2003 to 2007). Since the majority of UADR came into existence after the SEC rule change in 2008, this measure captures an investment by mutual fund $m$ in region $r$ using UADRs.

\footnotetext{
${ }^{14}$ We examine the mutual fund holdings obtained from Form N-Q. We rely on Form N-Q and not Form 13F because it provides holdings at the individual fund level, as opposed to the management company level, allowing us to focus on the actively managed funds for each management company
} 
The results for this analysis are reported in Table 8 Panel A. In column (1), the coefficient on Region_Pre $08_{m, r}$ is positive and significant, indicating that pre-existing exposure to a particular region is positively associated an investor's future use of UADR for the same region. In terms of economic significance, an additional dollar of pre-existing exposure to a particular region leads to close to two-dollars of additional investment in UADRs in the same region. In Column (2), we use an alternate measure of pre-existing exposure Region_ $07_{m, r}$, measured as the dollar amount of investment that mutual fund i invested into region $r$ in 2007 only. The statistically and economic significance remains similar. In Columns (3) and (4), we replace the main variables in Columns (1) and (2) with ranked versions and obtained similar results. Our results are consistent with U.S. institutional investors' foreign investment opportunity set being defined by region.

\subsubsection{Regional Comparability and the Investment Choices of UADR Investors}

If investors demand comparability to better evaluate potential investment opportunities, then comparability is more beneficial when a larger proportion of firms within an opportunity set are comparable. If U.S. institutional investors' opportunity sets can be defined by region, as shown in Table 8, Panel A, then it should be easier for these investors to utilize UADRs when there are a larger number of comparable firms within a region. Therefore, we test if institutional investors utilize UADRs to expand their portfolio by buying relative more UADRs for firms in regions where the average level of regional comparability is higher.

To achieve this goal, we first create the measure Mean Comp_Region ${ }_{i, t}$, which measures the average regional comparability of all firms in the region that firm $i$ is located in, excluding firm i's comparability. We then procced to estimate the following pooled firm-report date level regressions among all UADR firms between 2008 to 2013.

\section{$\$$ Holding $_{i, q}$}




$$
\begin{aligned}
& =\alpha+\beta_{1} \text { Mean_Comp_Region }_{i, t}+\beta_{2} \text { Comp_Region }_{i, t}+ \\
& \gamma \text { Controls }_{i, t}+\varepsilon_{m}
\end{aligned}
$$

In the above regression, $\$$ Holding $_{i, q}$ is the dollar amount of investments that all funds hold in the UADR for firm $i$ during quarter $q$. Controls $s_{i, t}$ include all the control varibels employed in Table $4 .{ }^{15}$

The results for this analysis are reported in Table 8, Panel B. In Column (1), the coefficient on Mean Comp_Region $i, t$ is positive and significant. This result indicates that as a group, U.S. institutional investors increase their foreign holdings significantly more in a firm via an UADR when the firm belongs to a region with higher average levels of regional comparability, or in regions with a more comparable set of firms. The coefficient for Comp_Region $i, t$ is also significantly positive, suggesting the firm's comparability is incrementally important to investors' decisions. In Column (2) we replace the dollar investment per firm quarter with a logged version of the variable, $\log \left(\$\right.$ Holding $\left._{i, q}\right)$. We find similar results using this approach. U.S. institutional investors increase their holdings using UADRS in firms that belong to regions with higher average levels of regional comparability. When taking into account that institutional ownership in the ADR market doubled through the purchase of UADRs following 2008, and that this growth is concentrated in more comparable firms, these results are consistent with the idea that regional comparability helps U.S. institutional investors expand their foreign investments.

\subsection{Additional Analyses}

\subsubsection{The Role of Accounting Quality}

\footnotetext{
${ }^{15} \mathrm{We}$ focus on the DKV measures in this analysis to maximize our sample size.
} 
In this sub-section, we further investigate the role Accounting_Qualityit plays in the relation between comparability and unsponsored cross-listing. If the underlying driver of investor's demand is driven by accounting comparability, then it stands to reason that the firm's accounting system must be sufficiently reliable for financial statement comparability to play a role. Therefore, we predict that the role of financial statement comparability increases when the quality of the accounting values reported by the firm is higher. To test this hypothesis, we add an interaction term to equation (4) and estimate the following regression:

Unsponsored $_{i}=\alpha+\beta_{1}$ Comparability $_{i t} \times$ High_Acc $_{i t}+\beta_{2}$ Comparability $_{i t}+$ $\beta_{3}$ AccountingQuality $_{i, t}+\gamma$ Controls $_{i t}+\varepsilon_{i t}$,

High_Acc $Q_{i t}$ it is an indicator variable which takes on the value of 1 if the value of Accounting_Qualityit is above the median and zero otherwise. Table 9 presents the regression results. In Panel A, we focus on our accounting-based comparability measures. Consistent with our predictions, in columns (1) and (2), we find that the positive association between Comp_Region ${ }_{i t} /$ Comp_Countryit and the creation of an UADR is stronger when a firm's accounting quality is sufficiently high. As an additional test, in Columns (3) and (4) we use an alternative measure of earnings quality. Specifically, we proxy for better financial reporting quality by the country's legal origin. Firms located in Common Law countries are expected to have better financial reporting quality. We reach similar conclusions use these alternative proxies. The relation between comparability at the regional and country level and the creation of an UADR is stronger when the firm's accounting quality is better. ${ }^{16}$

\footnotetext{
${ }^{16}$ For the sake of parsimony, we focus on the DKV comparability measures in this analysis. We draw similar inference when employing the textual based comparability measures.
} 
In Panel B, we examine the role of accounting quality on our results related to return synchronicity. As expected, we do not find that the relation between economic synchronicity and the selection of a firm for the creation of an UADR varies with the degree of accounting quality. Taken together, the results in Table 9 support our conjecture that our accounting-based comparability variables measure the extent to which two firms' accounting functions map similar economic events in a similar fashion.

\subsubsection{Changes in Comparability Following the Creation of an UADR.}

While our setting attempts to isolate the demand channel as in Fang et al. (2015), the UADR setting is substantially different with respect to the monitoring role of the U.S. investors. Investors in UADRs are passive investors with little (if any) influence on the underlying foreign firms. Therfore, we do not expect these investors to be able to affect the comparability of the firms they invest in, which is the central result in Fang et al. (2015).

To test this prediction, we examine whether there are any changes in comparability after the depositary bank creates an UADR for a particular firm. Specifically, for all the UADR firms, we calculate Comp_Countryi,t,Comp_Region ${ }_{i, t}$ and Comp_US $i, t$ between 2001 and 2013 and estimate the following regression:

$$
\text { Comparability }_{i t}=\alpha+\beta_{1} \text { Post }_{i t}+\beta_{2} \text { Control }_{i t}+\varepsilon_{i t} \text {, }
$$

Post $t_{i, t}$ is an indicator variable which takes the value of 1 if year $t$ is after the UADR listing date. Table 10 presents the regression result for each of our primary comparability measures. We find no evidence that the creation of an UADR changes the financial statement comparability of the underlying firm. For the sake of parsimony, we focus on the DKV comparability measures in 
this analysis. Once again, for brevity, we focus on the DKV comparability measures in this analysis. We reach similar conclusions when utilizing the textual based comparability measures

\section{Conclusions}

In this paper, we examine the drivers of the underlying demand for comparability by U.S. investors investing in foreign firms. We hypothesize that these investors face two types of nonmutually exclusive demands for comparability. First, investors may prefer information that is more comparable to U.S. GAAP, because they consider it a superior standard that is also more familiar. We label this type of demand as U.S. comparability. Second, investors may want to compare the information provided by foreign firms to their regional peers. In other words, comparability relative to other foreign firms can help U.S. investors evaluate international investments opportunities. We label this type of demand as regional comparability. From the perspective of the U.S. investor, U.S. comparability relates to the notion of convergence towards a uniform centralized standard, such as U.S. GAAP or IFRS, while regional comparability refers to local practice comparability among foreign firms. We exploit these two types of demands for comparability to highlight that comparability is not a one-size-fits-all solution, and that the demand for comparability is context specific and will vary for different users over time.

We utilize the unsponsored cross-listing market to examine the demand for comparability. One attractive feature of the unsponsored cross-listing market is that the decision to create an unsponsored ADR is made by the depositary bank and not the firm. As a result, the creation of an unsponsored cross-listing is exogenous to the firms' operating and reporting choices and, instead, is aimed at fulfilling trading activity in the foreign firm by U.S. investors. An additional advantage 
of the setting is that it identifies U.S. investors who want to increase the foreign exposure of their portfolio, and hence are likely to demand regional comparability.

We find that both the ex-ante selection of a firm for the creation of an unsponsored ADR and the ex-post trading volume in the unsponsored ADR are driven by the comparability of the underlying firm to other firms in the same region, and to a lesser extent to other firms in the same foreign country. We fail to find evidence that comparability to U.S. GAAP relates to these activities in the unsponsored ADR market. Our analysis further shows that the role of accounting comparability is incremental to that of economic synchronicity. Moreover, our findings are robust to the use of alternative measures of comparability. Taken together, our results are consistent with the demand for regional comparability by U.S. investors in the unsponsored ADR market.

In additional tests, we contrast our main findings with the role of comparability in the creation of sponsored ADR's and local (foreign) trading. Consistent with predictions arising from the bonding hypothesis and related findings in prior research, we find that firms with sponsored ADRs have accounting information that is more comparable to that of their US peers prior to crosslisting, and that the level of comparability increases following the cross-listing. We fail to find in association between the decision to cross-list and regional- or country-level comparability. These findings highlight the contrast between the sponsored and unsponsored cross-listing settings.

With respect to trading activity, we find a positive association between our regional measures (Comp Region and Comp Country) and trading in the firm's local market in our full sample, suggesting comparability benefits local investors. However, among cross-listed firms (both sponsored and unsponsored), higher levels of comparability to U.S. peers is negatively related to local trading volume. These results suggest firms with ADRS that increase their U.S. comparability sacrifice some local trading volume in order to facilitate raising foreign capital. 
Finally, we show that institutional investors' pre-existing exposure to a region predicts their future purchases of unsponsored ADRs in the same region. We also show that institutional investors increase their exposure relatively more using firms that belong to regions with higher average levels of regional comparability.

Our results imply that there is an implicit tradeoff in the costs and benefits of increased comparability to a specific set of firms. Foreign firms interested in attracting U.S. investors may have to trade-off between being more comparable to their regional peers versus peer U.S. firms. Understating the underlying demand for comparability illustrates the multi-dimensional aspect of comparability, suggesting that future research might examine not only if comparability matters in a specific context, but also to whom it is aimed for.

One important caveat in our paper is that our setting only allows us to examine the demand of U.S. investors in the unsponsored ADR setting. It is possible that U.S. investors with alternative objective functions, such as active direct ownership in a foreign firm, may also demand U.S. comparability. 


\section{References}

Bae, K. H., Tan, H., \& Welker, M. 2008. International GAAP differences: The impact on foreign analysts. The Accounting Review, 83(3), 593-628.

Barth, M. E., Landsman, W. R., Lang, M., \& Williams, C. 2012. Are IFRS-based and US GAAPbased accounting amounts comparable? Journal of Accounting and Economics, 54(1), 68-93.

Bradshaw, M. T., Bushee, B. J., \& Miller, G. S. 2004. Accounting choice, home bias, and US investment in non-US firms. Journal of Accounting Research, 42(5), 795-841.

Coffee Jr, J. C. 2002. Racing towards the top? The impact of cross-listings and stock market competition on international corporate governance. Columbia Law Review, 1757-1831.

Covrig, V. M., DeFond, M. L., \& Hung, M. 2007. Home bias, foreign mutual fund holdings, and the voluntary adoption of international accounting standards. Journal of Accounting Research, 45(1), 41-70.

Dechow, P., Ge, W., \& Schrand, C. 2010. Understanding earnings quality: A review of the proxies, their determinants and their consequences. Journal of Accounting and Economics, 50(2-3), 344401 .

DeFond, M., Hu, X., Hung, M., \& Li, S. 2011. The impact of mandatory IFRS adoption on foreign mutual fund ownership: The role of comparability. Journal of Accounting and Economics, 51(3), 240-258.

De Franco, G., Kothari, S. P., \& Verdi, R. S. 2011. The benefits of financial statement comparability. Journal of Accounting Research, 49(4), 895-931.

Deutsche Bank. 2012. Unsponsored ADRs: Evolution and opportunities. https://adr.db.com/drwebrebrand/media/publications/archive/2012

Deutsche Bank. 2018. Unsponsored ADRs - 2018 Market Review. https://adr.db.com/drwebrebrand/media/publications/unsponsored-adrs-2018-market-review

Doidge, C. 2004. US cross-listings and the private benefits of control: evidence from dual-class firms. Journal of Financial Economics, 72(3), 519-553.

Doidge, C., Karolyi, G. A., \& Stulz, R. M. 2004. Why are foreign firms listed in the US worth more? Journal of Financial Economics, 71(2), 205-238.

Fang, V. W., Maffett, M., \& Zhang, B. 2015. Foreign institutional ownership and the global convergence of financial reporting practices. Journal of Accounting Research, 53(3), 593-631.

Fang, V. W., Iselin, M., \& Zhang, G. 2017. Financial statement comparability: benefits and costs. SSRN Working Paper (No. 2858301). 
Financial Accounting Standards Board (FASB). 1980. Qualitative Characteristics of Accounting Information. Statement of Financial Accounting Concepts No. 2. Norwalk, CT: FASB.

Financial Accounting Standards Board (FASB). 2008. Exposure Draft of Conceptual Framework for Financial Reporting: FASB

Financial Accounting Standards Board (FASB). 2010 Concepts Statement No. 8. Norwalk, CT: FASB.

French, K. R. \& Poterba, J. M. 1991. Investor Diversification and International Equity Markets. American Economic Review, 81(2), 222-226.

Gopalan, R., \& Jayaraman, S. 2012. Private control benefits and earnings management: evidence from insider controlled firms. Journal of Accounting Research, 50(1), 117-157.

Hail, L., \& Leuz, C. 2009. Cost of capital effects and changes in growth expectations around US cross-listings. Journal of Financial Economics, 93(3), 428-454.

Huberman, G. 2001. Familiarity breeds investment. The Review of Financial Studies, 14(3), 659680 .

International Accounting Standards Board (IASB). 1989. Framework for the Preparation and Presentation of Financial Statements. IASB.

International Accounting Standards Board (IASB). 2008. Exposure Draft of an Improved Conceptual Framework for Financial Reporting. IASB.

International Accounting Standards Board (IASB). 2010. The Conceptual Framework for Financial Reporting. London, UK: IASB.

Iliev, P., Miller, D. P., \& Roth, L. 2014. Uninvited US Investors? Economic Consequences of Involuntary Cross-Listings. Journal of Accounting Research, 52(2), 473-519.

Kim, J. B., Li, L., Lu, L. Y., \& Yu, Y. 2016. Financial statement comparability and expected crash risk. Journal of Accounting and Economics, 61(2-3), 294-312.

Lang, M., Raedy, J. S., \& Yetman, M. H. 2003. How representative are firms that are cross-listed in the United States? An analysis of accounting quality. Journal of Accounting Research, 41(2), 363-386.

Lang, M., \& Stice-Lawrence, L. 2015. Textual analysis and international financial reporting: Large sample evidence. Journal of Accounting and Economics, 60(2-3), 110-135.

Leuz, C., Nanda, D., \& Wysocki, P. D. 2003. Earnings management and investor protection: an international comparison. Journal of Financial Economics, 69(3), 505-527. 
Pool, V. K., Stoffman, N., \& Yonker, S. E. 2012. No place like home: Familiarity in mutual fund manager portfolio choice. The Review of Financial Studies, 25(8), 2563-2599.

Securities and Exchange Commission (SEC). 2000. SEC Concept Release: International Accounting Standards. Available at http://sec.gov/rules/concept/34-42430.htm.

Wang, C. 2014. Accounting standards harmonization and financial statement comparability: Evidence from transnational information transfer. Journal of Accounting Research, 52(4), 955992. 


\begin{tabular}{lc}
\hline & Sample \\
\hline Non-U.S. Worldscope Observations between 2001 to 2013 & 216,805 \\
Less: Sponsor cross listed firms and firm-years after un-sponsored cross listing & $(17,780)$ \\
\cline { 2 - 2 } & 199,025 \\
Less: Firm-year observation without controls & $(45,941)$ \\
\cline { 2 - 2 } Less: Firm-year observations without EM1 EM2 and EM3 & 153,084 \\
& $(25,291)$ \\
\hline $\begin{array}{l}\text { Less: Firm-year observations without accounting comparability measure, earnings } \\
\text { or return comparability measures }\end{array}$ & 127,793 \\
\hline Final Sample & $52,741)$ \\
\hline
\end{tabular}


Table 2: Distribution of Observations by Region

\begin{tabular}{lccc}
\hline & N & Un-sponsored CL & Not CL \\
\hline Developed Markets & & & \\
Europe \& Middle East & 12,789 & 1,532 & 11,257 \\
Pacific & 22,950 & 1,633 & 21,317 \\
Emerging Markets & & & \\
America & 765 & 1 & 764 \\
Asia & 13,629 & 189 & 13,440 \\
Europe \& Middle East \& Africa & 1,919 & 93 & 1,826 \\
\hline Total & 52,052 & 3,448 & 48,604 \\
\hline
\end{tabular}

This table presents the distribution of observations by region. Regions are grouped according to the MSCI World Index. In the developed markets, Europe \& Middle East includes Austria, Belgium, Denmark, Finland, France, Germany, Ireland, Israel, Italy, Netherlands, Norway, Portugal, Spain, Sweden, Switzerland and the United Kingdom; Pacific includes Australia, Hong Kong, Japan, New Zealand and Singapore. In the emerging markets, America includes Brazil, Chile Colombia, Mexico and Peru; Europe, Middle East \& Africa includes Czech Republic, Egypt, Greece, Hungary, Poland, Qatar, Russia, South Africa, Turkey and United Arab Emirates; Asia includes China, India, Indonesia, Korea, Malaysia, Pakistan, Philippines, Taiwan and Thailand. 
Table 3: Descriptive Statistics

\begin{tabular}{lccc}
\hline & Mean & Median & STD \\
\hline Accounting Comparability Measures & & & \\
Comp_Region & -13.00 & -12.00 & 5.00 \\
Comp_Country & -10.00 & -9.00 & 7.00 \\
Comp_US & -22.00 & -23.00 & 14.00 \\
Return Synchronicity Measures & & & \\
Return_Region & 0.02 & 0.01 & 0.03 \\
Return_Country & 0.14 & 0.08 & 0.15 \\
Return_USA & 0.01 & 0.01 & 0.02 \\
Earnings Quality Measures & & & \\
Accounting_Quality & 0.04 & -0.43 & 1.31 \\
EM1 & 0.54 & 0.37 & 0.57 \\
EM2 & -0.84 & -0.96 & 0.31 \\
EM3 & 0.97 & 0.87 & 0.33 \\
Textual Comparability Measures & & & \\
Comp_NonUS_Text & & 0.07 \\
Comp_US_Text $i, t$ & 0.68 & 0.69 & 0.05 \\
Controls & 0.63 & 0.63 & \\
Closeheld_shr & & & 0.28 \\
Size & 0.49 & 0.48 & 1.80 \\
MB & 12.00 & 11.86 & 2.65 \\
Leverage & 1.76 & 1.21 & 0.18 \\
ROA & 0.23 & 0.21 & 0.10 \\
BA_Spread & 0.06 & 0.06 & 0.05 \\
Major_Index & 0.02 & 0.01 & 0.49 \\
IFRS/U_S. GAAP & 0.57 & 1.00 & 1.00 \\
\hline
\end{tabular}

This table presents descriptive statistics for all the variables employed in our analysis. All the variables are described in detail in Appendix A. All variables are winsorized at the 1\% and 99\% level. 
Table 4: Unsponsored Cross Listing and Accounting Comparability

\begin{tabular}{|c|c|c|c|c|c|c|}
\hline Panel A & (1) & (2) & (3) & (4) & $(5)$ & (6) \\
\hline Primary Sample & \multicolumn{6}{|c|}{ Unsponsored $_{i}$} \\
\hline Comp_Region $_{i, t}$ & $\begin{array}{c}0.028^{* * *} \\
(3.95)\end{array}$ & & & & $\begin{array}{l}0.028^{* * *} \\
(3.96)\end{array}$ & \\
\hline Comp_Country $_{i, t}$ & & $\begin{array}{l}0.039^{*} \\
(1.82)\end{array}$ & & & & $\begin{array}{l}0.040^{*} \\
(1.84)\end{array}$ \\
\hline Comp_US $S_{i, t}$ & $\begin{array}{l}-0.005 \\
(-0.44)\end{array}$ & $\begin{array}{l}-0.005 \\
(-0.24)\end{array}$ & & & $\begin{array}{l}-0.005 \\
(-0.40)\end{array}$ & $\begin{array}{l}-0.005 \\
(-0.27)\end{array}$ \\
\hline Return_Region $_{i, t}$ & & & $\begin{array}{c}0.586^{* * *} \\
(9.28)\end{array}$ & & $\begin{array}{l}0.585^{* * *} \\
(9.28)\end{array}$ & \\
\hline Return_Country $y_{i, t}$ & & & & $\begin{array}{c}0.053^{* * *} \\
(3.75)\end{array}$ & & $\begin{array}{c}0.053^{* * *} \\
(3.77)\end{array}$ \\
\hline Return_USA $A_{i, t}$ & & & $\begin{array}{l}0.129 \\
(0.57)\end{array}$ & $\begin{array}{l}0.220 \\
(0.96)\end{array}$ & $\begin{array}{l}0.128 \\
(0.56)\end{array}$ & $\begin{array}{c}0.223 \\
(0.98)\end{array}$ \\
\hline Accounting_Quality $_{i, t}$ & $\begin{array}{l}-0.001 \\
(-0.72)\end{array}$ & $\begin{array}{l}-0.001 \\
(-0.69)\end{array}$ & $\begin{array}{l}-0.001 \\
(-0.81)\end{array}$ & $\begin{array}{l}-0.001 \\
(-0.86)\end{array}$ & $\begin{array}{l}-0.001 \\
(-0.83)\end{array}$ & $\begin{array}{l}-0.001 \\
(-0.85)\end{array}$ \\
\hline Size $_{i, t}$ & $\begin{array}{c}0.038^{* * *} \\
(14.94)\end{array}$ & $\begin{array}{l}0.038^{* * *} \\
(14.93)\end{array}$ & $\begin{array}{l}0.036^{* * *} \\
(14.43)\end{array}$ & $\begin{array}{c}0.038^{* * *} \\
(14.79)\end{array}$ & $\begin{array}{l}0.036^{* * *} \\
(14.39)\end{array}$ & $\begin{array}{c}0.038^{* * *} \\
(14.74)\end{array}$ \\
\hline Closeheld_shr $r_{i, t}$ & $\begin{array}{c}-0.070^{* * *} \\
(-6.49)\end{array}$ & $\begin{array}{c}-0.069^{* * *} \\
(-6.46)\end{array}$ & $\begin{array}{c}-0.062^{* * *} \\
(-5.85)\end{array}$ & $\begin{array}{c}-0.063^{* * *} \\
(-5.89)\end{array}$ & $\begin{array}{c}-0.062^{* * *} \\
(-5.87)\end{array}$ & $\begin{array}{c}-0.063^{* * *} \\
(-5.89)\end{array}$ \\
\hline$M B_{i, t}$ & $\begin{array}{c}0.009^{* * *} \\
(7.03)\end{array}$ & $\begin{array}{c}0.009^{* * *} \\
(6.99)\end{array}$ & $\begin{array}{c}0.009^{* * *} \\
(7.00)\end{array}$ & $\begin{array}{c}0.009^{* * *} \\
(7.09)\end{array}$ & $\begin{array}{c}0.009^{* * *} \\
(7.01)\end{array}$ & $\begin{array}{c}0.009^{* * *} \\
(7.07)\end{array}$ \\
\hline Leverage $_{i, t}$ & $\begin{array}{l}-0.015 \\
(-1.14)\end{array}$ & $\begin{array}{l}-0.015 \\
(-1.12)\end{array}$ & $\begin{array}{l}-0.014 \\
(-1.04)\end{array}$ & $\begin{array}{l}-0.017 \\
(-1.29)\end{array}$ & $\begin{array}{l}-0.014 \\
(-1.05)\end{array}$ & $\begin{array}{l}-0.017 \\
(-1.28)\end{array}$ \\
\hline$R O A_{i, t}$ & $\begin{array}{c}0.065^{* * *} \\
(3.56)\end{array}$ & $\begin{array}{c}0.065^{* * *} \\
(3.53)\end{array}$ & $\begin{array}{c}0.057^{* * *} \\
(3.12)\end{array}$ & $\begin{array}{c}0.067^{* * *} \\
(3.66)\end{array}$ & $\begin{array}{c}0.058^{* * *} \\
(3.16)\end{array}$ & $\begin{array}{c}0.068^{* * *} \\
(3.69)\end{array}$ \\
\hline BA_Spread ${ }_{i, t}$ & $\begin{array}{l}-0.023 \\
(-1.47)\end{array}$ & $\begin{array}{l}-0.024 \\
(-1.51)\end{array}$ & $\begin{array}{l}-0.019 \\
(-1.19)\end{array}$ & $\begin{array}{l}-0.022 \\
(-1.43)\end{array}$ & $\begin{array}{l}-0.017 \\
(-1.07)\end{array}$ & $\begin{array}{l}-0.021 \\
(-1.35)\end{array}$ \\
\hline Major_Index $x_{i, t}$ & $\begin{array}{c}0.040^{* * * *} \\
(6.89)\end{array}$ & $\begin{array}{c}0.039^{* * * *} \\
(6.86)\end{array}$ & $\begin{array}{c}0.036^{\text {**** }} \\
(6.37)\end{array}$ & $\begin{array}{c}0.035^{* * * *} \\
(6.16)\end{array}$ & $\begin{array}{c}0.036^{* * *} \\
(6.37)\end{array}$ & $\begin{array}{c}0.035^{* * *} \\
(6.14)\end{array}$ \\
\hline IFRS/U.S. GAAP & $\begin{array}{c}0.047^{* * *} \\
(2.78)\end{array}$ & $\begin{array}{c}0.048^{* * *} \\
(2.84)\end{array}$ & $\begin{array}{c}0.042^{* *} \\
(2.44)\end{array}$ & $\begin{array}{c}0.058^{* * *} \\
(3.44)\end{array}$ & $\begin{array}{c}0.041^{* *} \\
(2.37)\end{array}$ & $\begin{array}{c}0.058^{* * *} \\
(3.42)\end{array}$ \\
\hline Country F.E. & Yes & Yes & Yes & Yes & Yes & Yes \\
\hline Industry F.E. & Yes & Yes & Yes & Yes & Yes & Yes \\
\hline Year F.E. & Yes & Yes & Yes & Yes & Yes & Yes \\
\hline Std. Error Cluster & Firm & Firm & Firm & Firm & Firm & Firm \\
\hline Observations & 52,052 & 52,052 & 52,050 & 52,050 & 52,050 & 52,050 \\
\hline Adjusted $R^{2}$ & 0.170 & 0.170 & 0.176 & 0.172 & 0.176 & 0.172 \\
\hline
\end{tabular}




\begin{tabular}{|c|c|c|c|c|}
\hline Panel B & (1) & (2) & (3) & (4) \\
\hline Non-IFRS Observations & \multicolumn{4}{|c|}{ Unsponsored $_{i}$} \\
\hline Comp_Region $_{i, t}$ & $\begin{array}{c}0.019^{* *} \\
(2.56)\end{array}$ & & $\begin{array}{c}0.020^{* * *} \\
(2.63)\end{array}$ & \\
\hline Comp_Country $_{i, t}$ & & $\begin{array}{c}0.069^{* *} \\
(2.30)\end{array}$ & & $\begin{array}{c}0.069^{* *} \\
(2.32)\end{array}$ \\
\hline Comp_US $S_{i, t}$ & $\begin{array}{l}-0.017 \\
(-1.08)\end{array}$ & $\begin{array}{l}-0.021 \\
(-0.67)\end{array}$ & $\begin{array}{l}-0.017 \\
(-1.10)\end{array}$ & $\begin{array}{l}-0.031 \\
(-0.68)\end{array}$ \\
\hline Return_Region $_{i, t}$ & & & $\begin{array}{l}0.119^{*} \\
(1.76)\end{array}$ & \\
\hline Return_Countryi,t & & & & $\begin{array}{l}0.013 \\
(0.83)\end{array}$ \\
\hline Return_USA $A_{i, t}$ & & & $\begin{array}{l}0.050 \\
(0.38)\end{array}$ & $\begin{array}{l}0.051 \\
(0.39)\end{array}$ \\
\hline Accounting_Quality $_{i, t}$ & $\begin{array}{c}0.001 \\
(0.42)\end{array}$ & $\begin{array}{c}0.001 \\
(0.50)\end{array}$ & $\begin{array}{l}0.001 \\
(0.45)\end{array}$ & $\begin{array}{c}0.001 \\
(0.49)\end{array}$ \\
\hline Size $_{i, t}$ & $\begin{array}{l}0.049^{* * *} \\
(10.97)\end{array}$ & $\begin{array}{l}0.049^{* * *} \\
(10.97)\end{array}$ & $\begin{array}{l}0.048^{* * *} \\
(10.88)\end{array}$ & $\begin{array}{c}0.048^{* * *} \\
(10.88)\end{array}$ \\
\hline Closeheld_shr $r_{i, t}$ & $\begin{array}{c}-0.052^{* * *} \\
(-3.93)\end{array}$ & $\begin{array}{c}-0.053^{* * *} \\
(-3.96)\end{array}$ & $\begin{array}{c}-0.052^{* * *} \\
(-3.89)\end{array}$ & $\begin{array}{c}-0.052^{* * *} \\
(-3.78)\end{array}$ \\
\hline$M B_{i, t}$ & $\begin{array}{c}0.008^{* * *} \\
(4.53)\end{array}$ & $\begin{array}{c}0.008^{* * *} \\
(4.50)\end{array}$ & $\begin{array}{c}0.008^{* * *} \\
(4.50)\end{array}$ & $\begin{array}{c}0.008^{* * *} \\
(4.50)\end{array}$ \\
\hline Leverage $_{i, t}$ & $\begin{array}{c}-0.037^{* *} \\
(-2.18)\end{array}$ & $\begin{array}{c}-0.035^{* *} \\
(-2.08)\end{array}$ & $\begin{array}{c}-0.037^{* *} \\
(-2.15)\end{array}$ & $\begin{array}{c}-0.035^{* *} \\
(-2.08)\end{array}$ \\
\hline$R O A_{i, t}$ & $\begin{array}{l}0.020 \\
(0.84)\end{array}$ & $\begin{array}{l}0.020 \\
(0.83)\end{array}$ & $\begin{array}{c}0.021 \\
(0.85)\end{array}$ & $\begin{array}{c}0.021 \\
(0.87)\end{array}$ \\
\hline BA_Spread ${ }_{i, t}$ & $\begin{array}{l}-0.012 \\
(-0.59)\end{array}$ & $\begin{array}{l}-0.015 \\
(-0.70)\end{array}$ & $\begin{array}{l}-0.010 \\
(-0.49)\end{array}$ & $\begin{array}{l}-0.014 \\
(-0.63)\end{array}$ \\
\hline Major_Index $x_{i, t}$ & $\begin{array}{c}-0.030^{* * *} \\
(-4.97)\end{array}$ & $\begin{array}{c}-0.030^{* * *} \\
(-4.98)\end{array}$ & $\begin{array}{c}-0.031^{* * *} \\
(-5.04)\end{array}$ & $\begin{array}{c}-0.031^{* * *} \\
(-5.18)\end{array}$ \\
\hline U.S. $G A A P_{i, t}$ & $\begin{array}{l}0.022 \\
(0.45)\end{array}$ & $\begin{array}{l}0.022 \\
(0.44)\end{array}$ & $\begin{array}{c}0.021 \\
(0.43)\end{array}$ & $\begin{array}{l}0.024 \\
(0.48)\end{array}$ \\
\hline Country F.E. & Yes & Yes & Yes & Yes \\
\hline Industry F.E. & Yes & Yes & Yes & Yes \\
\hline Year F.E. & Yes & Yes & Yes & Yes \\
\hline Std. Error Cluster & Firm & Firm & Firm & Firm \\
\hline Observations & 20,651 & 20,651 & 20,651 & 20,651 \\
\hline Adjusted $R^{2}$ & 0.181 & 0.181 & 0.181 & 0.181 \\
\hline
\end{tabular}




\begin{tabular}{|c|c|c|}
\hline $\begin{array}{l}\text { Panel C } \\
\text { Text Based Measures }\end{array}$ & \multicolumn{2}{|c|}{ Unsponsored $_{i}$} \\
\hline Comp_NonUS_Texti,t & $\begin{array}{l}0.262^{* *} \\
(2.01)\end{array}$ & $\begin{array}{l}0.251^{*} \\
(1.93)\end{array}$ \\
\hline Comp_US_Texti,t & $\begin{array}{l}-0.027 \\
(-0.18)\end{array}$ & $\begin{array}{l}-0.032 \\
(-0.22)\end{array}$ \\
\hline Return_Region $_{i, t}$ & & $\begin{array}{l}0.543^{* * *} \\
(5.08)\end{array}$ \\
\hline Return_USA $A_{i, t}$ & & $\begin{array}{l}0.125 \\
(0.28)\end{array}$ \\
\hline Accounting_Quality ${ }_{i, t}$ & $\begin{array}{l}0.002 \\
(0.73)\end{array}$ & $\begin{array}{l}0.001 \\
(0.26)\end{array}$ \\
\hline Size $_{i, t}$ & $\begin{array}{l}0.094^{* * *} \\
(16.11)\end{array}$ & $\begin{array}{l}0.081^{* * *} \\
(15.41)\end{array}$ \\
\hline Closeheld_shri,t & $\begin{array}{c}-0.154^{* * *} \\
(-6.48)\end{array}$ & $\begin{array}{l}-0.130^{* * *} \\
(-5.77)\end{array}$ \\
\hline$M B_{i, t}$ & $\begin{array}{l}0.022^{* * *} \\
(7.85)\end{array}$ & $\begin{array}{l}0.021^{* * *} \\
(7.94)\end{array}$ \\
\hline Leverage $_{i, t}$ & $\begin{array}{l}-0.062^{*} \\
(-1.85)\end{array}$ & $\begin{array}{l}-0.051 \\
(-1.59)\end{array}$ \\
\hline$R O A_{i, t}$ & $\begin{array}{l}0.144^{* * *} \\
(3.42)\end{array}$ & $\begin{array}{l}0.100^{* *} \\
(2.54)\end{array}$ \\
\hline BA_Spread $i, t$ & $\begin{array}{l}-0.164^{* *} \\
(-2.23)\end{array}$ & $\begin{array}{l}-0.140^{* *} \\
(-2.06)\end{array}$ \\
\hline Major_Indexi,t & $\begin{array}{l}0.037^{* * *} \\
(2.66)\end{array}$ & $\begin{array}{l}0.049^{* * *} \\
(3.73)\end{array}$ \\
\hline IFRS/U.S. GAAP ${ }_{i, t}$ & $\begin{array}{l}0.010 \\
(0.18)\end{array}$ & $\begin{array}{l}0.015 \\
(0.28)\end{array}$ \\
\hline $\begin{array}{l}\text { Country F.E. } \\
\text { Industry F.E. } \\
\text { Year F.E. } \\
\text { Std. Error Cluster }\end{array}$ & $\begin{array}{l}\text { Yes } \\
\text { Yes } \\
\text { Yes } \\
\text { Firm }\end{array}$ & $\begin{array}{l}\text { Yes } \\
\text { Yes } \\
\text { Yes } \\
\text { Firm }\end{array}$ \\
\hline $\begin{array}{l}\text { Observations } \\
\text { Adjusted } R^{2}\end{array}$ & $\begin{array}{l}14,925 \\
0.291\end{array}$ & $\begin{array}{c}14,925 \\
0.293 \\
\end{array}$ \\
\hline $\begin{array}{l}\text { This table presents the resul } \\
\text { sample between } 2001 \text { and } 2 \\
\text { statements are not prepared } \\
\text { textual similarity of financia } \\
\text { data are obtained from Worl } \\
\text { if the underlying firm was } \\
\text { comparability between firm } i \\
\text { comparability between firm } \\
\text { comparability between firm } \\
\text { the foreign firm's } 10 \mathrm{~K} \text { to its } \\
10 \mathrm{~K} \text { to its non-U.S. peers, } \\
\text { principal component of EM } 1 \\
\text { are in parentheses. } * * *, * *,\end{array}$ & $\begin{array}{l}\text { ion of equat } \\
\text { anel B inclu } \\
\text { th IFRS. Fol } \\
\text { een peer-firt } \\
\text { data from D } \\
\text { ny point bet } \\
\text { firms in the s } \\
\text { r firms in th } \\
\text { s in the sam } \\
\text { Comp_Nont } \\
\text { s outside of } \\
\text { higher value } \\
\text { ficance at the }\end{array}$ & $\begin{array}{l}\text { Irm-year observations in our } \\
\text { s where the firm's financial } \\
\text { ace }(2015) \text {, Panel C uses the } \\
\text { f comparability. Accounting } \\
\text { indicator variable equal to } 1 \\
\text { Region }_{i, t} \text { is the accounting } \\
\text { Oomp_US } U S_{i, t} \text { is the accounting } \\
\text { the textual comparability of } \\
\text { rability of the foreign firm's } \\
\text { unting_Quality } \\
\text { aality. Coefficient } t \text {-statistics } \\
\text { levels, respectively. All the }\end{array}$ \\
\hline
\end{tabular}


Table 5: UADR Trading Volume and Accounting Comparability

\begin{tabular}{|c|c|c|c|c|}
\hline $\begin{array}{l}\text { Panel A } \\
\text { Primary Sample }\end{array}$ & (1) & (2) & $\begin{array}{c}(3) \\
\text { ln_Volume }_{U S, C L+1}\end{array}$ & (4) \\
\hline Comp_Region $_{i, t}$ & $\begin{array}{l}1.874^{* *} \\
(2.53)\end{array}$ & & $\begin{array}{l}1.872^{* *} \\
(2.53)\end{array}$ & \\
\hline Comp_Country $_{i, t}$ & & $\begin{array}{c}2.862^{* * *} \\
(3.51)\end{array}$ & & $\begin{array}{c}2.855^{* * *} \\
(3.51)\end{array}$ \\
\hline Comp_US $S_{i, t}$ & $\begin{array}{l}0.329 \\
(0.28)\end{array}$ & $\begin{array}{l}-0.648 \\
(-0.52)\end{array}$ & $\begin{array}{l}0.207 \\
(0.18)\end{array}$ & $\begin{array}{l}-0.654 \\
(-0.53)\end{array}$ \\
\hline Return_Countryi,t & & & & $\begin{array}{l}1.225 \\
(1.25)\end{array}$ \\
\hline Return_Region $_{i, t}$ & & & $\begin{array}{l}4.605^{*} \\
(1.68)\end{array}$ & \\
\hline Return_USA $A_{i, t}$ & & & $\begin{array}{l}-2.788^{*} \\
(-1.87)\end{array}$ & $\begin{array}{l}-2.711^{*} \\
(-1.76)\end{array}$ \\
\hline Accounting_Quality $_{i, t}$ & $\begin{array}{l}-0.031 \\
(-0.18)\end{array}$ & $\begin{array}{l}-0.073 \\
(-0.40)\end{array}$ & $\begin{array}{l}-0.070 \\
(-0.38)\end{array}$ & $\begin{array}{l}-0.031 \\
(-0.18)\end{array}$ \\
\hline Avg_Price_US $S_{i, t}$ & $\begin{array}{l}0.003 \\
(0.72)\end{array}$ & $\begin{array}{l}0.004 \\
(0.78)\end{array}$ & $\begin{array}{l}0.003 \\
(0.71)\end{array}$ & $\begin{array}{l}0.003 \\
(0.72)\end{array}$ \\
\hline Size $_{i, t}$ & $\begin{array}{c}0.789^{* * *} \\
(4.62)\end{array}$ & $\begin{array}{c}0.793^{* * *} \\
(4.57)\end{array}$ & $\begin{array}{c}0.756^{* * *} \\
(4.37)\end{array}$ & $\begin{array}{c}0.788^{* * *} \\
(4.59)\end{array}$ \\
\hline Closeheld_shr $r_{i, t}$ & $\begin{array}{c}-1.717^{* * *} \\
(-3.35)\end{array}$ & $\begin{array}{c}-1.622^{* * *} \\
(-3.14)\end{array}$ & $\begin{array}{c}-1.570^{* * *} \\
(-3.05)\end{array}$ & $\begin{array}{c}-1.715^{* * *} \\
(-3.35)\end{array}$ \\
\hline$M B_{i, t}$ & $\begin{array}{l}0.058 \\
(1.11)\end{array}$ & $\begin{array}{l}0.046 \\
(0.85)\end{array}$ & $\begin{array}{l}0.048 \\
(0.90)\end{array}$ & $\begin{array}{l}0.058 \\
(1.12)\end{array}$ \\
\hline Leverage $_{i, t}$ & $\begin{array}{l}-1.164 \\
(-1.21)\end{array}$ & $\begin{array}{l}-1.235 \\
(-1.27)\end{array}$ & $\begin{array}{l}-1.220 \\
(-1.25)\end{array}$ & $\begin{array}{l}-1.188 \\
(-1.23)\end{array}$ \\
\hline$R O A_{i, t}$ & $\begin{array}{l}3.469^{* *} \\
(2.02)\end{array}$ & $\begin{array}{l}3.871^{* *} \\
(2.22)\end{array}$ & $\begin{array}{l}3.674^{* *} \\
(2.16)\end{array}$ & $\begin{array}{l}3.452^{* * *} \\
(2.01)\end{array}$ \\
\hline BA_Spread ${ }_{i, t}$ & $\begin{array}{c}-0.729^{* *} \\
(-2.02)\end{array}$ & $\begin{array}{l}-0.197 \\
(-0.55)\end{array}$ & $\begin{array}{l}-0.210 \\
(-0.59)\end{array}$ & $\begin{array}{c}-0.725^{* *} \\
(-2.00)\end{array}$ \\
\hline Major_Index ${ }_{i, t}$ & $\begin{array}{l}0.247 \\
(0.48)\end{array}$ & $\begin{array}{l}0.187 \\
(0.38)\end{array}$ & $\begin{array}{l}0.220 \\
(0.44)\end{array}$ & $\begin{array}{l}0.230 \\
(0.44)\end{array}$ \\
\hline IFRS/U.S. GAAP ${ }_{i, t}$ & $\begin{array}{c}2.270^{* *} \\
(2.33)\end{array}$ & $\begin{array}{c}2.107^{* *} \\
(2.06)\end{array}$ & $\begin{array}{l}2.346^{* *} \\
(2.33)\end{array}$ & $\begin{array}{l}2.284^{* *} \\
(2.35)\end{array}$ \\
\hline Country F.E. & Yes & Yes & Yes & Yes \\
\hline Industry F.E. & Yes & Yes & Yes & Yes \\
\hline Acc. Std. F.E. & Yes & Yes & Yes & Yes \\
\hline Std. Error Cluster & Firm & Firm & Firm & Firm \\
\hline $\begin{array}{l}\text { Observations } \\
\text { Adjusted } R^{2}\end{array}$ & $\begin{array}{c}899 \\
0.172\end{array}$ & $\begin{array}{c}899 \\
0.163\end{array}$ & $\begin{array}{c}899 \\
0.165\end{array}$ & $\begin{array}{c}899 \\
0.171\end{array}$ \\
\hline
\end{tabular}




\begin{tabular}{|c|c|c|}
\hline $\begin{array}{l}\text { Panel B } \\
\text { Text Based Measures }\end{array}$ & (1) & (2) \\
\hline Comp_NonUS_Text ${ }_{i, t}$ & $\begin{array}{c}1.513^{* * *} \\
(2.68)\end{array}$ & $\begin{array}{c}1.528^{* * *} \\
(2.61)\end{array}$ \\
\hline Comp_US_Text $t_{i, t}$ & $\begin{array}{l}-0.528 \\
(-1.18)\end{array}$ & $\begin{array}{l}-0.567 \\
(-1.17)\end{array}$ \\
\hline Return_Region $_{i, t}$ & & $\begin{array}{l}6.964^{*} \\
(1.67)\end{array}$ \\
\hline Return_USA $A_{i, t}$ & & $\begin{array}{l}-1.637 \\
(-0.11)\end{array}$ \\
\hline Accounting_Quality $_{i, t}$ & $\begin{array}{l}-0.060 \\
(-0.19)\end{array}$ & $\begin{array}{l}-0.045 \\
(-0.14)\end{array}$ \\
\hline Avg_Price_US $S_{i, t}$ & $\begin{array}{c}0.135^{* * *} \\
(6.14)\end{array}$ & $\begin{array}{c}0.136^{* * *} \\
(6.26)\end{array}$ \\
\hline Size $_{i, t}$ & $\begin{array}{c}1.343^{* * *} \\
(5.09)\end{array}$ & $\begin{array}{c}1.290^{* * *} \\
(4.86)\end{array}$ \\
\hline Closeheld_shri,t & $\begin{array}{c}-1.551^{* *} \\
(-2.04)\end{array}$ & $\begin{array}{c}-1.487^{*} \\
(-1.95)\end{array}$ \\
\hline$M B_{i, t}$ & $\begin{array}{c}0.279^{* * *} \\
(2.93)\end{array}$ & $\begin{array}{c}0.277^{* * *} \\
(2.91)\end{array}$ \\
\hline Leverage $_{i, t}$ & $\begin{array}{l}-1.436 \\
(-0.97)\end{array}$ & $\begin{array}{l}-1.352 \\
(-0.91)\end{array}$ \\
\hline$R O A_{i, t}$ & $\begin{array}{c}5.923^{* *} \\
(2.52)\end{array}$ & $\begin{array}{c}5.691^{* *} \\
(2.41)\end{array}$ \\
\hline BA_Spread ${ }_{i, t}$ & $\begin{array}{l}5.475^{*} \\
(1.94)\end{array}$ & $\begin{array}{l}5.289^{*} \\
(1.92)\end{array}$ \\
\hline Major_Index ${ }_{i, t}$ & $\begin{array}{l}-1.165 \\
(-1.56)\end{array}$ & $\begin{array}{l}-1.214 \\
(-1.59)\end{array}$ \\
\hline IFRS/U.S. GAAP ${ }_{i, t}$ & $\begin{array}{l}-0.515 \\
(-0.58)\end{array}$ & $\begin{array}{l}-1.089 \\
(-1.15)\end{array}$ \\
\hline $\begin{array}{l}\text { Country F.E. } \\
\text { Industry F.E. } \\
\text { Acc. Std. F.E. } \\
\text { Std. Error Cluster }\end{array}$ & $\begin{array}{l}\text { Yes } \\
\text { Yes } \\
\text { Yes } \\
\text { Firm }\end{array}$ & $\begin{array}{l}\text { Yes } \\
\text { Yes } \\
\text { Yes } \\
\text { Firm }\end{array}$ \\
\hline $\begin{array}{l}\text { Observations } \\
\text { Adjusted } R^{2}\end{array}$ & $\begin{array}{c}679 \\
0.336\end{array}$ & $\begin{array}{c}679 \\
0.338\end{array}$ \\
\hline
\end{tabular}


This table presents results for the estimation of equation (6). Panel A includes 899 firms that were cross-listed using unsponsored ADRs, between 2008 and 2013, inclusive and have available U.S. OTC trading data. In_Volume US,CL+1 is the dollar trading volume in the UADR, in the U.S. market, one year after firm $i$ was cross-listed. Comp_Region ${ }_{i, t}$ is the accounting comparability between firm $i$ and all the other firms in the same industry and region. Comp_Countryi,t is the accounting comparability between firm $\mathrm{i}$ and all the other firms in the same industry and country. Comp_US $S_{i, t}$ is the accounting comparability between firm $i$ and all US firms in the same industry. Panel B includes 679 firms from Panel A and have available date to calculate textual comparability. Comp_US_Text $t_{i, t}$ is the textual comparability of the foreign firm's $10 \mathrm{~K}$ to its' U.S. peers while Comp_NonUS_Text $t_{i, t}$ is the textual comparability of the foreign firm's $10 \mathrm{~K}$ to its non-U.S. peers, for all peer firms outside of the firm's own country***,**, and $*$ denote significance at the $1 \%, 5 \%$, and $10 \%$ (two-sided) levels, respectively. All the variables are described in detail in Appendix A. 
Table 6: Sponsored Cross Listing and Accounting Comparability

\begin{tabular}{|c|c|c|c|}
\hline & $\begin{array}{c}(1) \\
\text { Comp_US }\end{array}$ & $\begin{array}{c}(2) \\
\text { Comp_Region }_{i, t}\end{array}$ & $\stackrel{(3)}{\text { Comp_Country }}{ }_{i, t}$ \\
\hline ADR_Level23i & $\begin{array}{c}0.050^{* *} \\
(2.20)\end{array}$ & $\begin{array}{l}0.315 \\
(0.89)\end{array}$ & $\begin{array}{l}-0.002 \\
(-0.06)\end{array}$ \\
\hline ADR_Level23i ${ }^{*}$ Post $_{i, t}$ & $\begin{array}{l}0.090^{*} \\
(1.86)\end{array}$ & $\begin{array}{l}-0.209 \\
(-0.55)\end{array}$ & $\begin{array}{l}0.041 \\
(0.68)\end{array}$ \\
\hline Post $_{i, t}$ & $\begin{array}{l}-0.006 \\
(-0.14)\end{array}$ & $\begin{array}{l}0.053 \\
(0.38)\end{array}$ & $\begin{array}{l}-0.083^{*} \\
(-1.80)\end{array}$ \\
\hline Accounting_Quality $_{i, t}$ & $\begin{array}{c}-0.006^{* * *} \\
(-4.82)\end{array}$ & $\begin{array}{c}0.003 \\
(0.19)\end{array}$ & $\begin{array}{c}-0.009^{* * *} \\
(-4.75)\end{array}$ \\
\hline Size $_{i, t}$ & $\begin{array}{c}0.004^{* * *} \\
(6.31)\end{array}$ & $\begin{array}{c}0.023^{* * *} \\
(3.79)\end{array}$ & $\begin{array}{l}0.002 \\
(1.54)\end{array}$ \\
\hline Closeheld_shr $r_{i, t}$ & $\begin{array}{l}0.003 \\
(0.80)\end{array}$ & $\begin{array}{l}0.020 \\
(0.51)\end{array}$ & $\begin{array}{l}0.006 \\
(0.95)\end{array}$ \\
\hline$M B_{i, t}$ & $\begin{array}{l}-0.001^{*} \\
(-1.79)\end{array}$ & $\begin{array}{l}0.001 \\
(0.46)\end{array}$ & $\begin{array}{l}-0.001 \\
(-1.38)\end{array}$ \\
\hline Leverage $_{i, t}$ & $\begin{array}{c}-0.035^{* * *} \\
(-6.64)\end{array}$ & $\begin{array}{l}-0.064 \\
(-1.53)\end{array}$ & $\begin{array}{c}-0.054^{* * *} \\
(-6.49)\end{array}$ \\
\hline$R O A_{i, t}$ & $\begin{array}{c}0.041^{* * *} \\
(6.10)\end{array}$ & $\begin{array}{c}0.059 \\
(0.96)\end{array}$ & $\begin{array}{c}0.030^{* * *} \\
(3.30)\end{array}$ \\
\hline BA_Spread $i, t$ & $\begin{array}{c}-0.000^{* *} \\
(-1.96)\end{array}$ & $\begin{array}{l}0.000 \\
(0.50)\end{array}$ & $\begin{array}{l}-0.000 \\
(-0.79)\end{array}$ \\
\hline Major_Index ${ }_{i, t}$ & $\begin{array}{c}0.008^{* * *} \\
(3.84)\end{array}$ & $\begin{array}{l}0.002 \\
(0.08)\end{array}$ & $\begin{array}{c}0.013^{* * *} \\
(4.48)\end{array}$ \\
\hline IFRS/U.S. GAAP ${ }_{i, t}$ & $\begin{array}{l}0.005^{*} \\
(1.78)\end{array}$ & $\begin{array}{c}0.268^{* * * *} \\
(8.66)\end{array}$ & $\begin{array}{c}0.031^{* * *} \\
(7.67)\end{array}$ \\
\hline $\begin{array}{l}\text { Country F.E. } \\
\text { Industry F.E. } \\
\text { Acc. Std. F.E. } \\
\text { Std. Error Cluster }\end{array}$ & $\begin{array}{l}\text { Yes } \\
\text { Yes } \\
\text { Yes } \\
\text { Firm }\end{array}$ & $\begin{array}{c}\text { Yes } \\
\text { Yes } \\
\text { Yes } \\
\text { Firm }\end{array}$ & $\begin{array}{c}\text { Yes } \\
\text { Yes } \\
\text { Yes } \\
\text { Firm }\end{array}$ \\
\hline $\begin{array}{l}\text { Observations } \\
\text { Adjusted } R^{2}\end{array}$ & $\begin{array}{c}54,183 \\
0.188 \\
\end{array}$ & $\begin{array}{c}54,183 \\
0.182 \\
\end{array}$ & $\begin{array}{c}54,183 \\
0.207 \\
\end{array}$ \\
\hline
\end{tabular}

This table presents results for the estimation of equation (7). It includes 54,183 firm-years observations, which comprise of our full sample of foreign firms (level 2 and 3 sponsored, unsponsored and non-cross listed foreign firms). Comp_US $S_{i, t}$ is the accounting comparability between firm $i$ and all US firms in the same industry. Comp_Region $n_{i, t}$ is the accounting comparability between firm $i$ and all the other firms in the same industry and region. Comp_Countryi,t is the accounting comparability between firm $i$ and all the other firms in the same industry and country. ADR_Level23i is an indicator variable which takes the value of 1 if firm $i$ will be level 2 or 3 cross-listed in the U.S. at any point between 2008 and 2013. Post $t_{i}$ is an indicator variable which takes the value of 1 if year $t$ is equal to or after firm $i$ is cross listed in the U.S. $* * *, * *$, and $*$ denote significance at the $1 \%, 5 \%$, and $10 \%$ (two-sided) levels, respectively. All the variables are described in detail in Appendix A. 
Table 7: Local Trading Volume and Accounting Comparability

\begin{tabular}{|c|c|c|}
\hline & $\begin{array}{c}\text { (1) } \\
\text { Worldscope Sample }\end{array}$ & $\begin{array}{c}(2) \\
\text { Cross Listed firms }\end{array}$ \\
\hline & \multicolumn{2}{|c|}{ ln_Volume Local,$t+1_{1}$} \\
\hline Comp_Region $_{i, t}$ & $\begin{array}{c}0.329^{* * *} \\
(3.42)\end{array}$ & $\begin{array}{l}1.125^{*} \\
(1.83)\end{array}$ \\
\hline Comp_Country $_{i, t}$ & $\begin{array}{c}0.438^{* * *} \\
(3.63)\end{array}$ & $\begin{array}{l}1.205^{*} \\
(1.95)\end{array}$ \\
\hline Comp_US $S_{i, t}$ & $\begin{array}{l}-0.030 \\
(-1.10)\end{array}$ & $\begin{array}{c}-2.171^{* *} \\
(-2.04)\end{array}$ \\
\hline Accounting_Quality $_{i, t}$ & $\begin{array}{l}0.070^{* * *} \\
(4.23)\end{array}$ & $\begin{array}{l}-0.103 \\
(-0.58)\end{array}$ \\
\hline Avg_Price $_{i, t}$ & $\begin{array}{l}-0.000 \\
(-1.25)\end{array}$ & $\begin{array}{c}-0.000^{* *} \\
(-2.08)\end{array}$ \\
\hline Size $_{i, t}$ & $\begin{array}{l}0.932^{* * * *} \\
(47.29)\end{array}$ & $\begin{array}{c}0.818^{* * * *} \\
(7.54)\end{array}$ \\
\hline Closeheld_shri,t & $\begin{array}{l}-1.123^{* * *} \\
(-13.73)\end{array}$ & $\begin{array}{l}-0.787 \\
(-0.81)\end{array}$ \\
\hline$M B_{i, t}$ & $\begin{array}{l}0.271^{* * *} \\
(20.54)\end{array}$ & $\begin{array}{l}-0.092 \\
(-1.12)\end{array}$ \\
\hline Leverage $_{i, t}$ & $\begin{array}{c}-0.583^{* * *} \\
(-3.91)\end{array}$ & $\begin{array}{l}-1.850^{*} \\
(-1.74)\end{array}$ \\
\hline$R O A_{i, t}$ & $\begin{array}{c}1.374^{* * *} \\
(5.51)\end{array}$ & $\begin{array}{l}1.475 \\
(1.10)\end{array}$ \\
\hline BA_Spread ${ }_{i, t}$ & $\begin{array}{l}-0.004^{* * *} \\
(-11.72)\end{array}$ & $\begin{array}{c}0.002^{* * *} \\
(4.64)\end{array}$ \\
\hline Major_Index ${ }_{i, t}$ & $\begin{array}{l}0.718^{* * *} \\
(12.78)\end{array}$ & $\begin{array}{l}0.970^{*} \\
(1.68)\end{array}$ \\
\hline IFRS/U.S. GAAP $P_{i, t}$ & $\begin{array}{c}-0.913^{* * *} \\
(-6.88)\end{array}$ & $\begin{array}{l}0.332 \\
(0.43)\end{array}$ \\
\hline Country F.E. & Yes & Yes \\
\hline Industry F.E. & Yes & Yes \\
\hline Acc. Std. F.E. & Yes & Yes \\
\hline Std. Error Cluster & Firm & Firm \\
\hline Observations & 54,183 & 5,579 \\
\hline Adjusted $R^{2}$ & 0.546 & 0.581 \\
\hline
\end{tabular}

This table presents results for the estimation of equation (8). Column (1) includes our full sample of 54,183 foreign firm-years (level 2 and 3 sponsored, unsponsored and non-cross listed foreign firms). In_Volume Local,,$+1_{\text {is }}$ the sum of the daily trading volume in year $\mathrm{t}+1$ at the foreign firm's local market. Comp_US $S_{i, t}$ is the accounting comparability between firm $i$ and all US firms in the same industry. Comp_Region $n_{i, t}$ is the accounting comparability between firm $i$ and all the other firms in the same industry and region. Comp_Country $y_{i, t}$ is the accounting comparability between firm $\mathrm{i}$ and all the other firms in the same industry and country. Column (2) includes 5,579 cross listed firm-years observations only. $* * *, * *$, and $*$ denote significance at the $1 \%, 5 \%$, and $10 \%$ (two-sided) levels, respectively. All the variables are described in detail in Appendix A. 
Table 8: Institutional Investors' Unsponsored ADR Holdings

\begin{tabular}{|c|c|c|c|c|}
\hline \multicolumn{5}{|c|}{ Panel A: Pre-2008 and Post-2008 ADR Holdings } \\
\hline & (1) & (2) & (3) & (4) \\
\hline & \multicolumn{2}{|c|}{ UADR_Post08 $8_{m, r}$} & \multicolumn{2}{|c|}{$R \_U A D R \_P o s t 08_{m, r}$} \\
\hline Region_Pre08 ${ }_{m, r}$ & $\begin{array}{c}1.964^{* * *} \\
(2.97)\end{array}$ & & & \\
\hline Region_07 $m, r$ & & $\begin{array}{l}1.965^{* *} \\
(2.12)\end{array}$ & & \\
\hline$R \_$Region_Pre08 ${ }_{m, r}$ & & & $\begin{array}{l}1.053^{* * *} \\
(10.20)\end{array}$ & \\
\hline$R \_$Region_07 $m, r$ & & & & $\begin{array}{c}1.426^{* * *} \\
(9.77)\end{array}$ \\
\hline Avg. Asset Under & 0.001 & 0.001 & 0.000 & $0.000^{* *}$ \\
\hline Management $_{m, p o s t}$ & $(1.35)$ & $(0.81)$ & $(1.64)$ & $(2.35)$ \\
\hline Avg. Fund_Return ${ }_{m, p o s t}$ & $\begin{array}{l}4.134^{* *} \\
(2.35)\end{array}$ & $\begin{array}{l}5.423^{* *} \\
(2.17)\end{array}$ & $\begin{array}{l}0.001^{* * *} \\
(12.24)\end{array}$ & $\begin{array}{c}0.001^{* * *} \\
(8.59)\end{array}$ \\
\hline Avg. Fund Flow ${ }_{m, p o s t}$ & $\begin{array}{l}-0.017 \\
(-1.15) \\
\end{array}$ & $\begin{array}{l}-0.002 \\
(-0.12) \\
\end{array}$ & $\begin{array}{c}0.000^{* * *} \\
(2.89) \\
\end{array}$ & $\begin{array}{c}0.000^{* *} \\
(2.58) \\
\end{array}$ \\
\hline Std. Cluster & Manager & Manager & Manager & Manager \\
\hline Observations & 679 & 541 & 679 & 541 \\
\hline Adjusted $R^{2}$ & 0.393 & 0.204 & 0.263 & 0.311 \\
\hline
\end{tabular}

Panel A presents the results from the estimation of equation (9). Estimates are obtained using panel cross-sectional manager-region level regressions. Column (1) and (3) include mutual fund managers that held at least one UADR between 2009 to 2013 and at least one ADR between 2003 and 2007. Column (2) and (4) include mutual fund managers that held at least one UADR between 2009 to 2013 and at least one ADR in 2007. The dependent variable UADR_Post08 is the dollar amount invested by mutual fund $m$ in UADRs from region $r$ post 2008 (2009 to 2013). $R \_U A D R \_P o s t 08$ is a ranked version of the variable UADR_Post08. Region_Pre08 ${ }_{m, r}$ is the average dollar amount that mutual fund $m$ invested in region $r$ between 2003 to 2007. Region_07 $m$, is the average dollar amount that mutual fund $m$ invested in region $r$ during 2007. R_Region_Pre08 ${ }_{m, r}$ and $R \_$Region_07 $m, r$ are the ranked version of Region_Pre08 ${ }_{m, r}$ and Region_07 $7_{m, r}$ respectively. 
Panel B: Regional Comparability and Investors Holdings

\begin{tabular}{lcc}
\hline & $(1)$ & $(2)$ \\
& $\$$ Holding $_{i, q}$ & Log $\left(\$\right.$ Holding $\left._{i, q}\right)$ \\
\hline Mean Comp_Region $_{i, t}$ & $0.502^{* * *}$ & $0.232^{*}$ \\
& $(2.69)$ & $(1.93)$ \\
Comp_Region $_{i, t}$ & $0.125^{*}$ & $0.179^{*}$ \\
& $(1.79)$ & $(1.89)$ \\
Controls from Table 4 & & \\
& Yes & Yes \\
Country F.E. & & No \\
Firm F.E. & No & Yes \\
Report Quarter F.E. & Yes & Yes \\
Std. Error Cluster & Yes & 13,455 \\
\hline Observations & Industry, Report Quarter & Industry, Report Quarter \\
Adjusted $R^{2}$ & 13,455 & 0.552 \\
\hline
\end{tabular}

Panel B presents the results from the estimation of equation (10). Estimates are obtained using pooled firm-report date level regressions from 2008 to 2013. The sample includes unsponsored ADR firms between 2008 and 2013. \$ Holding $_{i, t}$ is the dollar amount of investment that all U.S. mutual funds invested in firm $i$ during report quarter $q$. Mean Comp_Region ${ }_{i, t}$ is the average Comp_Region ${ }_{i, t}$ of all the firms inside the region that firm $i$ is located in, excluding firm i's Comp_Region ${ }_{i, t}$.Comp_Region ${ }_{i, t}$ is the accounting comparability between firm $i$ and all the other firms in the same industry and region. $\log \left(\$\right.$ Holding $\left._{i, t}\right)$ is the natural $\log$ of the dollar amount of investment that all U.S. mutual funds invested in firm $i$ during report quarter $q$. 
Table 9: The Role of Accounting Quality

\begin{tabular}{|c|c|c|c|c|}
\hline Panel A & (1) & (2) & (5) & (6) \\
\hline Accounting Comparability & \multicolumn{4}{|c|}{ Unsponsored $_{i}$} \\
\hline High_Acc $Q_{i, t} \times C o m p \_$Region ${ }_{i, t}$ & $\begin{array}{c}0.028^{* * *} \\
(3.50)\end{array}$ & & & \\
\hline High_Acc $Q_{i, t} \times C o m p \_C o u n t r y, t$ & & $\begin{array}{l}0.049^{*} \\
(1.95)\end{array}$ & & \\
\hline CommonLaw $_{i, t} \times$ Comp_Region $_{i, t}$ & & & $\begin{array}{l}0.023^{*} \\
(1.94)\end{array}$ & \\
\hline CommonLaw $_{i, t} \times$ Comp_Country $_{i, t}$ & & & & $\begin{array}{l}0.010^{*} \\
(1.87)\end{array}$ \\
\hline Comp_Region $_{i, t}$ & $\begin{array}{l}-0.015 \\
(-1.38)\end{array}$ & & $\begin{array}{c}0.055^{* * *} \\
(6.77)\end{array}$ & \\
\hline Comp_Country $y_{i, t}$ & & $\begin{array}{l}-0.020 \\
(-1.11)\end{array}$ & & $\begin{array}{l}-0.025 \\
(-1.09)\end{array}$ \\
\hline IFRS_USGAP ${ }_{i, t}$ & $\begin{array}{c}0.047^{* * *} \\
(2.78)\end{array}$ & $\begin{array}{l}0.048^{* * *} \\
(2.83)\end{array}$ & $\begin{array}{l}0.116^{* * *} \\
(17.57)\end{array}$ & $\begin{array}{l}0.116^{* * *} \\
(17.48)\end{array}$ \\
\hline CommonLaw $_{i, t}$ & & & $\begin{array}{c}0.060^{* * *} \\
(7.11)\end{array}$ & $\begin{array}{c}0.067^{* * *} \\
(6.91)\end{array}$ \\
\hline$H i g h \_A c c Q_{i, t}$ & $\begin{array}{l}0.001 \\
(0.55)\end{array}$ & $\begin{array}{l}0.001 \\
(0.23)\end{array}$ & & \\
\hline Accounting_Quality ${ }_{i, t}$ & & & $\begin{array}{c}-0.002^{*} \\
(-1.75)\end{array}$ & $\begin{array}{c}-0.003^{*} \\
(-1.88)\end{array}$ \\
\hline Controls from Table 4 & Yes & Yes & Yes & Yes \\
\hline Country F.E. & Yes & Yes & No & No \\
\hline Industry F.E. & Yes & Yes & Yes & Yes \\
\hline Year F.E. & Yes & Yes & Yes & Yes \\
\hline Std. Error Cluster & Firm & Firm & Firm & Firm \\
\hline Observations & 52,052 & 52,052 & 52,052 & 52,052 \\
\hline Adjusted $R^{2}$ & 0.172 & 0.172 & 0.139 & 0.138 \\
\hline
\end{tabular}




\begin{tabular}{|c|c|c|c|c|}
\hline Panel B & (1) & $(2)$ & (3) & (4) \\
\hline Return Synchronicity & \multicolumn{4}{|c|}{ Unsponsored $_{i}$} \\
\hline${\overline{H i g h} \_A c c Q_{i, t} \times \text { Ret_Region }_{i, t}}$ & $\begin{array}{l}0.094 \\
(0.88)\end{array}$ & & & \\
\hline High_Acc $Q_{i, t} \times$ Ret_Country $y_{i, t}$ & & $\begin{array}{l}0.011 \\
(0.53)\end{array}$ & & \\
\hline CommonLaw $_{i, t} \times$ Ret_Region $_{i, t}$ & & & $\begin{array}{l}0.071 \\
(0.48)\end{array}$ & \\
\hline CommonLaw $_{i, t} \times$ Ret_Country $_{i, t}$ & & & & $\begin{array}{l}0.058 \\
(1.39)\end{array}$ \\
\hline Ret_Region ${ }_{i, t}$ & $\begin{array}{c}0.604^{* * *} \\
(7.41)\end{array}$ & & $\begin{array}{c}0.630^{* * *} \\
(8.42)\end{array}$ & \\
\hline Ret_Country ${ }_{i, t}$ & & $\begin{array}{c}0.081^{* * *} \\
(4.99)\end{array}$ & & $\begin{array}{c}0.078^{* * *} \\
(4.75)\end{array}$ \\
\hline IFRS_USGAP $P_{i, t}$ & $\begin{array}{c}0.042^{* *} \\
(2.45)\end{array}$ & $\begin{array}{c}0.058^{* * *} \\
(3.41)\end{array}$ & $\begin{array}{c}0.041^{* *} \\
(2.40)\end{array}$ & $\begin{array}{c}0.056^{* * *} \\
(3.28)\end{array}$ \\
\hline CommonLaw $_{i, t}$ & & & $\begin{array}{c}0.944^{* * *} \\
(5.30)\end{array}$ & $\begin{array}{c}0.941^{* * *} \\
(6.86)\end{array}$ \\
\hline$H i g h \_A c c Q_{i, t}$ & $\begin{array}{l}0.008 \\
(0.62)\end{array}$ & $\begin{array}{l}0.008 \\
(0.86)\end{array}$ & & \\
\hline Accounting_Quality $_{i, t}$ & & & $\begin{array}{l}-0.001 \\
(-0.91)\end{array}$ & $\begin{array}{l}-0.001 \\
(-0.92)\end{array}$ \\
\hline Controls from Table 4 & Yes & Yes & Yes & Yes \\
\hline Country F.E. & Yes & Yes & No & No \\
\hline Industry F.E. & Yes & Yes & Yes & Yes \\
\hline Year F.E. & Yes & Yes & Yes & Yes \\
\hline Std. Error Cluster & Firm & Firm & Firm & Firm \\
\hline Observations & 52,050 & 52,050 & 52,050 & 52,050 \\
\hline Adjusted $R^{2}$ & 0.170 & 0.171 & 0.134 & 0.139 \\
\hline
\end{tabular}

Table 9 presents results for the estimation of equation (11). The analysis includes all firm-year observations in our sample between 2001 and 2013, inclusive. The regressions include all the control variables employed in Table 4. Accounting data are obtained from Worldscope and return data from Datastream. High_AccQ $Q_{i, t}$ is an indicator variable taking the value of 1 if firm i's Accounting_Quality ${ }_{i, t}$ is above median and zero otherwise. CommonLawi,t is an indicator variable which takes the value of one if the company is located in a common law country. Coefficient $t$ statistics are in parentheses. $* * *, * *$, and $*$ denote significance at the $1 \%, 5 \%$, and $10 \%$ (two-sided) levels, respectively. All the variables are defined in Appendix A. 
Table 10: Change in Comparability Following the creation of an UADR

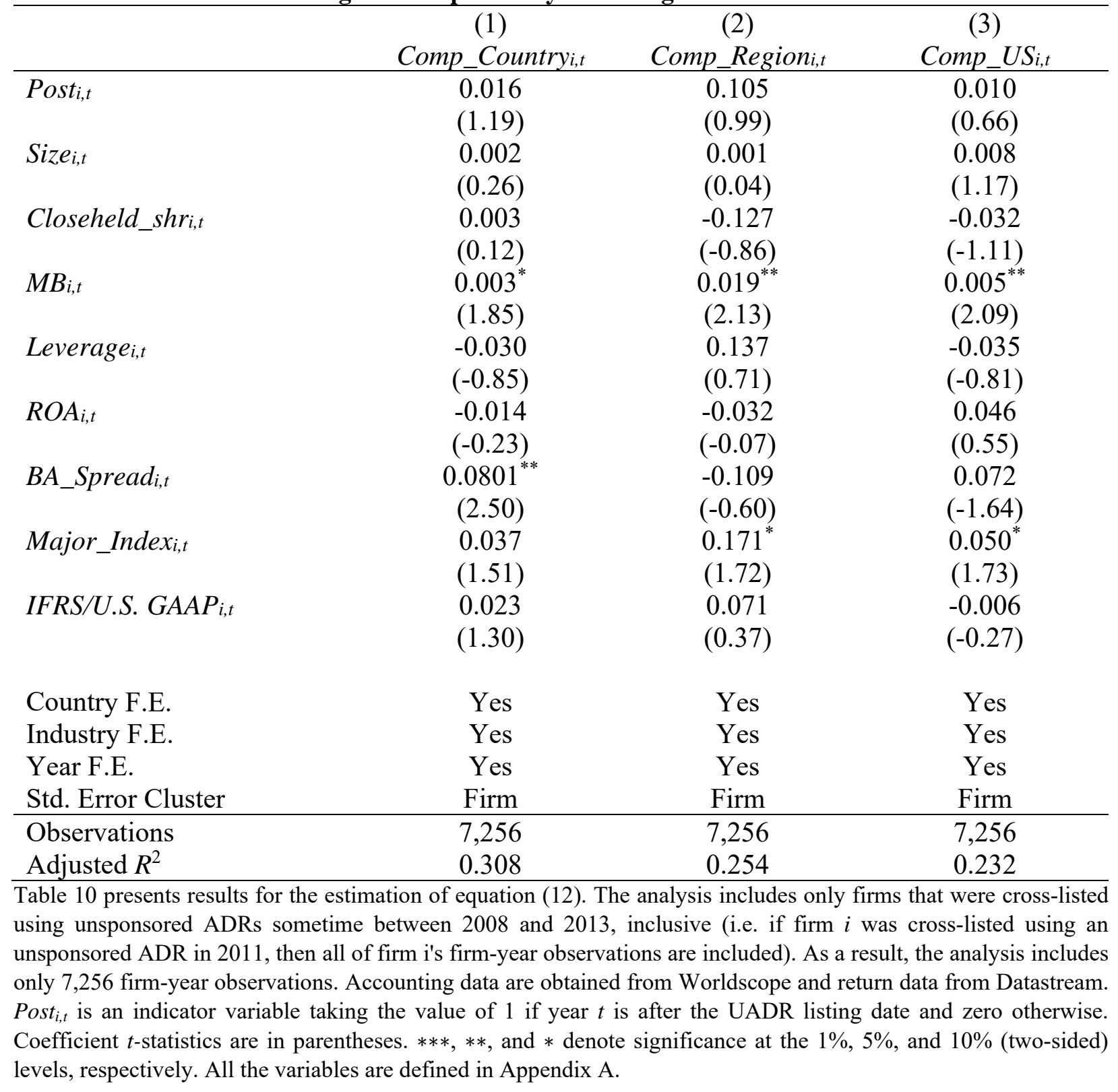




\section{Appendix A}

Variables

Unsponsored $_{i}$

Comp_Region ${ }_{i t}$

Comp_Countryit

\section{Definition}

Unsponsored is an indicator variable equal to 1 if the underlying firm was cross-listed using an unsponsored ADR at any point between 2008 and 2013.

First, we estimate the following rolling-window time-series regression using the past five years of data from $t-4$ to $t$ for each non-U.S. firm i-year t:

- $N I_{i t}=\alpha_{i}+\beta_{i} R_{i t}+\varepsilon_{i t}$

- $E(N I)_{i i t}=\hat{\alpha}_{i}+\hat{\beta}_{i} R_{i t}$

- E(NI) $)_{i j t}=\hat{\alpha}_{j}+\hat{\beta}_{j} R_{i t}$

- $\mathrm{COMP}_{\mathrm{ijt}}=-\frac{1}{5} \sum_{t-4}^{t}\left|E(N I)_{i i t}-E(N I)_{i j t}\right|$

Next, we estimate comparability to firms in the same region, COMP REGIONijt, for each possible combination of firm $i$ and firm $j$ in the same region within the same one-digit ICB industry group during a given year $t$.

Finally, we calculate our firm-year measure of comparability to the firms in the same region, COMP REGIONit, as the average of the full set of COMP REGIONijt multiplied by 100 (as in Fang, Maffett and Zhang 2015).

First, we estimate the following rolling-window time-series regression using the past five years of data from $t-4$ to $t$ for each non-U.S. firm i-year t:

- $N I_{i t}=\alpha_{i}+\beta_{i} R_{i t}+\varepsilon_{i t}$

- $E(N I)_{i i t}=\hat{\alpha}_{i}+\hat{\beta}_{i} R_{i t}$

- $E(N I)_{i j t}=\hat{\alpha}_{j}+\hat{\beta}_{j} R_{i t}$

- $\mathrm{COMP}_{\mathrm{ijt}}=-\frac{1}{5} \sum_{t-4}^{t}\left|E(N I)_{i i t}-E(N I)_{i j t}\right|$

Next, we estimate comparability to firms in the same country, COMP COUNTTRYijt, for each possible combination of firm $i$ and firm $j$ in the same country within the same one-digit ICB industry group during a given year $t$.

Finally, we calculate our firm-year measure of comparability to the firms in the same country, COMP COUNTRYit, as the average of the full set of COMP COUNTRYijt multiplied by 100 (as in Fang, Maffett and Zhang 2015). 
Comp_US

First, we estimate the following rolling-window time-series regression using the past five years of data from $\mathrm{t}-4$ to $\mathrm{t}$ for each non-U.S. firm i-year $t$ :

- $N I_{i t}=\alpha_{i}+\beta_{i} R_{i t}+\varepsilon_{i t}$

- $E(N I)_{i i t}=\hat{\alpha}_{i}+\hat{\beta}_{i} R_{i t}$

- $E(N I)_{i j t}=\hat{\alpha}_{j}+\hat{\beta}_{j} R_{i t}$

- $\mathrm{COMP}_{\mathrm{ijt}}=-\frac{1}{5} \sum_{t-4}^{t}\left|E(N I)_{i i t}-E(N I)_{i j t}\right|$

Next, we estimate comparability to firms in the U.S., COMP USijt, for each possible combination of a non-U.S. firm $i$ and a U.S. firm $j$ within the same one-digit ICB industry group during a given year $t$.

Finally, we calculate our firm-year measure of comparability to firms in the U.S., COMP USit, as the average of the full set of COMP USijt multiplied by 100 (as in Fang, Maffett and Zhang 2015).

Accounting_Quality First principal component of EM1, EM2 and EM3.

EM1

EM1 is calculated as the firm level standard deviation of operating income divided by standard deviation of operating cash flow:

(Std of Net Income)/ (Std of NCFO)

Where:

- NCFO is calculated using operating income less accruals

- Accruals is calculated as ( $\Delta$ total current assets - $\Delta$ cash $)$ - ( $\Delta$ total current liabilities - $\Delta$ short-term debt - $\Delta$ taxes payable) depreciation expense

- Std is calculated using the past 5 years of data

EM2

EM2 is calculated as the firm level correlation between changes in accrual and changes in cash flow from operation (NCFO)

Where:

- NCFO is calculated using operating income less accruals

- Accruals is calculated as ( $\Delta$ total current assets - $\Delta$ cash $)$ - ( $\Delta$ total current liabilities - $\Delta$ short-term debt - $\Delta$ taxes payable) depreciation expense

- Correlation is calculated using the past 5 years of data

EM3

- EM3 is calculated as the absolute value of accruals divided by absolute value of operating cash flow

$\left[\operatorname{Abs}(\text { Accrualst }) / \operatorname{Abs}\left(\mathrm{CFO}_{\mathrm{t}}\right)\right]^{*}-1$ 
Where:

- NCFO is calculated using operating income less accruals

- Accruals is calculated as ( $\Delta$ total current assets - $\Delta$ cash $)$ - ( $\Delta$ total current liabilities - $\Delta$ short-term debt - $\Delta$ taxes payable) depreciation expense.

Closeheld_shri,t The percentage of closely held shares.

Size $_{i, t}$

Natural log of the book value of total assets.

$M B_{i, t}$

Leverage $i, t$

The market value of equity divided by book value of equity.

$R O A_{i, t}$

The ratio of total debt to total asset.

Equals return on assets, measured as net income divided by total assets.

Major_Indexi,t An indicator variable which takes on the value of one if a firm is listed on a major index.

BA_Spread ${ }_{i, t}$

IFRS/U.S. GAAP ${ }_{i, t}$

The average daily bid-ask spread of a firm $i$ in year $t$.

An indicator variable which takes the value of one if the company's financial statements are prepared in accordance with IFRS or U.S. GAAP. We define a firm as using IFRS or U.S. GAAP for all observations where the accounting standard in Worldscope is equal to IFRS or U.S. GAAP, and for all firmyears in countries that adopted IFRS, where IFRS reporting is Mandatory.

U.S. GAAP $i, t \quad$ An indicator variable which takes the value of one if the company's financial statements are prepared in accordance with U.S. GAAP. We define a firm as using U.S. GAAP for all observations where the accounting standard in Worldscope is equal to U.S. GAAP.

Comp_NonUS_Text $t_{i, t}$ The textual similarity of foreign firm i's $10 \mathrm{~K}$ to all its non-U.S. peers, excluding firms from firm i's home country. The measure is obtained from Lang and Stice-Lawrence (2015). It equals the median of each firm (i)'s $10 \mathrm{~K}$ cosine similarity with all its nonU.S. peers in a given year.

Comp_US_Text $t_{i, t} \quad$ The textual similarity of a foreign firm i's $10 \mathrm{~K}$ to all its U.S. peers. The measure is obtained from Lang and Stice-Lawrence (2015). It equals the median of each firm (i)'s $10 \mathrm{~K}$ cosine similarity with all its U.S. peers in a given year.

In_Volume $U S, C L+1 \quad$ The dollar trading volume of an UADR in the U.S. OTC market for the year after the creation of an unsponsored cross-listing for firm $i$ (year CL+1). Trading volume is obtained from Bloomberg.

Avg_Price_US $S_{i, t} \quad$ The average stock price of firm $i$ in the U.S. OTC market in year $\mathrm{t}$. 
ADR_Level23i

Post ${ }_{i, t}$

In_Volume Local,$t+1$

UADR_Post08 ${ }_{m, r}$

R_UADR_Post08m,r

Region_Pre08m,r

Region_07m,r

$R \_R e g i o n \_P r e 08_{m, r}$

R_Region_07m,r

Avg. Asset Under

Managementm,post

Avg.

Fund_Return

Avg. Fund

Flowm,post

$\log (\$ P e r$

Countryt,m)

Log(\# Stocks Per

Countryt,m)

Log(\# Countriest,m)

Post

Asset Under

Management $t, m$

Fund_Return ${ }_{t-1, m}$

Fund Flow $t, m$

Return_Region ${ }_{\mathrm{it}}$
$A D R \_$Level23i is an indicator variable equal to 1 if the underlying firm was cross-listed using level 2 or level 3 ADR at any point between 2008 and 2013.

Post $_{i}$ is an indicator variable which takes the value of 1 if year $t$ is equal to or after firm $i$ is cross listed in the U.S.

The dollar trading volume of a foreign non-US firm in their local market. Trading volume is obtained from Datastream.

The average additional dollar invested by mutual fund $m$ in an UADR from region $r$, during the post SEC rule change period (2009 to 2013).

The ranked version of UADR_Post08m,r.

The average dollar mutual fund $\mathrm{m}$ invested in region $r$ in the preSEC rule change period (2003 to 2007).

The dollar amount of investment that mutual fund $\mathrm{m}$ invested in region $r$ in 2007.

The ranked version of Region_Pre08 $m, r$.

The ranked version of Region_07 $m, r$.

The average total dollar amount of assets that mutual fund $\mathrm{m}$ managed in the post-SEC rule change period (2008 to 2013).

The average return that mutual fund $\mathrm{m}$ earned in the post-SEC rule change period (2008 to 2013).

The average dollar of new investment that mutual fund $\mathrm{m}$ received in the post-SEC rule change period (2008 to 2013).

Nature log of the dollar amount of investments that fund $m$ holds in non-U.S. holdings, in each country.

Nature log of the number of stocks that fund $m$ holds in nonU.S. holdings, in each country.

Nature log of the number of countries that fund $m$ invested in.

Indicator variable which takes on the value of one for the periods after the SEC rule change (2009 to 2013).

The total dollar amount of assets that mutual fund $\mathrm{m}$ managed in year $\mathrm{t}$.

The return that mutual fund $m$ earned in year $t$.

The dollar of new investment that mutual fund $m$ received in year t.

- We estimate the following rolling-window time-series regression using the past 48 months of data from $t-48$ to $t$ for each non-U.S. firm i-year t:

- $\operatorname{AvgRet}_{t}=\alpha_{i}+\beta_{i} \operatorname{Ret}_{i t}+\varepsilon_{i t}$ 
- We calculate the comparability of the firm to the region, COMP

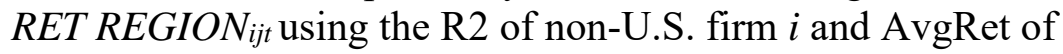
the region's firms within the same two-digit SIC industry group.

Return_Country $\mathrm{it}_{\mathrm{it}} \quad$ - We estimate the following rolling-window time-series regression using the past 48 months of data from $t-48$ to $t$ for each non-U.S. firm i-year t:

- AvgRet $_{t}=\alpha_{i}+\beta_{i}$ Ret $_{i t}+\varepsilon_{i t}$

- We calculate the comparability of the firm to the country, COMP RET Countryijt using the R2 of non-U.S. firm $i$ and AvgRet of the country's firms within the same two-digit SIC industry group.

Return_USA it - We estimate the following rolling-window time-series regression using the past 48 months of data from $t-48$ to $t$ for each non-U.S. firm i-year t:

- AvgRet $_{t}=\alpha_{i}+\beta_{i}$ Ret $_{i t}+\varepsilon_{i t}$

- We calculate the comparability of the firm to the U.S., COMP RET US $S_{i j t}$ using the R2 of non-U.S. firm $i$ and AvgRet of the U.S. firms within the same two-digit SIC industry group. 


\section{Appendix B}

Panel A: Average Investment in UADR and Sponsor ADR Per Fund

\begin{tabular}{lcccc} 
& 2003 to 2008 & 2009 to 2013 & \% Change \\
\hline \$ Investment in UADR per fund & $\$ 17,453,139$ & $\$ 227,821,417$ & $1205.3 \%$ \\
\$ Investment in Sponsor ADR per fund & $\$ 132,203,605$ & $\$ 170,864,347$ & $29.2 \%$ \\
\% Investment in UADR out of total holdings & $1 \%$ & $7 \%$ & $910.7 \%$ \\
\% Investment in Sponsor ADR out of total holdings & $5 \%$ & $5 \%$ & $0.1 \%$ \\
\# firms held through UADR per fund & 0.95 & 13.06 & $1280.7 \%$ \\
\# firms held through Sponsored ADR per fund & 17.55 & 17.53 & $-0.1 \%$ \\
\hline
\end{tabular}

Panel B: Average Overseas Investment via ADRs

\begin{tabular}{lccc} 
& 2003 to 2008 & 2009 to 2013 & $\%$ Change \\
\hline \$ Investment per country per fund & $\$ 13,034,579.0$ & $\$ 89,045,722.0$ & $583 \%$ \\
\# stocks per country per fund & 2.66 & 8.59 & $223 \%$ \\
\# countries per fund & 5.06 & 4.74 & $-6 \%$ \\
\hline
\end{tabular}


Appendix C - Alternative Comparability Measures

\begin{tabular}{|c|c|c|}
\hline & $(1)$ & $(2)$ \\
\hline Comp_Region_Barth ${ }_{i, t}$ & $\begin{array}{c}0.020^{* * *} \\
(3.90)\end{array}$ & \\
\hline Comp_Country_Barth ${ }_{i, t}$ & & $\begin{array}{c}0.036^{* * *} \\
(3.73)\end{array}$ \\
\hline Comp_US_Barth ${ }_{i, t}$ & $\begin{array}{l}-0.005 \\
(-1.20)\end{array}$ & $\begin{array}{l}-0.017 \\
(-1.34)\end{array}$ \\
\hline Accounting_Quality $_{i, t}$ & $\begin{array}{l}-0.001 \\
(-0.62)\end{array}$ & $\begin{array}{l}-0.002 \\
(-0.99)\end{array}$ \\
\hline Size $_{i, t}$ & $\begin{array}{l}0.041^{\text {*** }} \\
(13.80)\end{array}$ & $\begin{array}{c}0.039^{* * *} \\
(13.93)\end{array}$ \\
\hline Closeheld_shr $r_{i, t}$ & $\begin{array}{c}-0.079^{* * *} \\
(-6.20)\end{array}$ & $\begin{array}{c}-0.073^{* * *} \\
(-6.00)\end{array}$ \\
\hline$M B_{i, t}$ & $\begin{array}{c}0.011^{* * *} \\
(6.49)\end{array}$ & $\begin{array}{c}0.011^{* * *} \\
(6.48)\end{array}$ \\
\hline Leverage $_{i, t}$ & $\begin{array}{l}-0.013 \\
(-0.78)\end{array}$ & $\begin{array}{l}-0.014 \\
(-0.88)\end{array}$ \\
\hline$R O A_{i, t}$ & $\begin{array}{c}0.071^{* * *} \\
(2.95)\end{array}$ & $\begin{array}{l}0.056^{* *} \\
(2.46)\end{array}$ \\
\hline BA_Spread ${ }_{i, t}$ & $\begin{array}{l}-0.017 \\
(-1.08)\end{array}$ & $\begin{array}{l}-0.020 \\
(-1.35)\end{array}$ \\
\hline Major_Index ${ }_{i, t}$ & $\begin{array}{c}0.044^{* * * *} \\
(6.51)\end{array}$ & $\begin{array}{c}0.049^{* * *} \\
(7.46)\end{array}$ \\
\hline U.S. GAAP ${ }_{i, t}$ & $\begin{array}{c}0.053^{* * *} \\
(2.85)\end{array}$ & $\begin{array}{c}0.054^{* * *} \\
(2.94)\end{array}$ \\
\hline Country F.E. & Yes & Yes \\
\hline Industry F.E. & Yes & Yes \\
\hline Year F.E. & Yes & Yes \\
\hline Std. Error Cluster & Firm & Firm \\
\hline Observations & 52,052 & 52,052 \\
\hline Adjusted $R^{2}$ & 0.183 & 0.180 \\
\hline
\end{tabular}

This table presents the results for the estimation of equation (4). The analysis includes all firm-year observations in our sample between 2001 and 2013, inclusive. Accounting data are obtained from Worldscope and return data from Datastream. Unsponsored is an indicator variable equal to 1 if the underlying firm was cross-listed at any point between 2008 and 2013. Comp_Region_Barth ${ }_{i, t}$ is the accounting comparability between firm $i$ and all the other firms in the same industry and region estimated using the methods outlined in Barth et al. (2012). Comp_Country_Barth ${ }_{i, t}$ is the accounting comparability between firm $i$ and all the other firms in the same industry and country estimated using the methods outlined in Barth et al. (2012). Comp_US_Barth $h_{i, t}$ is the accounting comparability between firm $i$ and all US firms in the same industry estimated using the methods outlined in Barth et al. (2012). Accounting_Quality ${ }_{i, t}$ is the first principal component of EM1, EM2 and EM3, higher value indicates better accounting quality. Coefficient $t$ statistics are in parentheses. $* * *, * *$, and $*$ denote significance at the $1 \%, 5 \%$, and $10 \%$ (two-sided) levels, respectively. All the variables are described in detail in Appendix A. 